IFN Working Paper No. 862, 2011

\title{
Globalization and Absolute Poverty - A Panel Data Study
}

Andreas Bergh and Therese Nilsson 


\title{
Globalization and absolute poverty - a panel data study
}

\author{
Andreas Bergha and Therese Nilsson ${ }^{b}$
}

Using panel data from more than 100 countries around the world from 1988 through 2007, this paper examines the relationship between economic and social globalization and absolute income poverty ex post. We use the globalization index developed by Dreher (2006) and the World Bank poverty estimates. Using a fixed-effect panel based on five-year averages and using a "long run" first difference regression, we find a robust negative correlation between globalization and poverty. We further examine mechanisms and robustness by separately analyzing the effects of components of economic (trade flows and trade policies) and social globalization (information flows, personal contact and cultural proximity) respectively, controlling for growth, education, inflation, urbanization, and government consumption. Results suggest that information flows and more liberal trade restrictions are robustly negatively correlated with absolute poverty. While growth decreases poverty in the long run, only a small part of the poverty-reducing effect of globalization is mediated via growth.

JEL codes: D30, F15, I32

Keywords: Globalization, poverty, panel data

Financial support from the Tom Hedelius' and Jan Wallander's Research Foundations and from the Swedish International Development Cooperation Agency (SIDA) is gratefully acknowledged.

\footnotetext{
${ }^{a}$ Lund University and the Research Institute of Industrial Economics (IFN), Box 55665, SE-102 15, Stockholm. Andreas.bergh@ifn.se

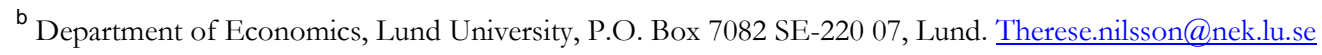


The effect of globalization on the world's poor is a highly debated topic. Typically defined as the process by which different countries become more closely integrated, globalization has been portrayed both as a cause of poverty and as a solution to the same problem. Due to data limitations, research has thus far been unable to provide conclusive evidence on the relationship between globalization and absolute poverty, as measured by the population share living below one PPP dollar per day. Existing research either concludes that economic openness is likely to reduce poverty because it has been shown to increase growth (Bhagwati and Srinivasan (2002), Dollar and Kraay (2004)), or examines ex ante poverty using CGE-models (Ganuza et al., 2005). There are also some cross-country studies focusing on actual poverty outcomes such as Heshmati (2007), but the few existing panel data studies cover a very limited set of countries such as Agénor (2004) with $\mathrm{N}=16 .{ }^{1}$

This paper examines how globalization is linked to changes in ex post absolute poverty in a way that is detailed enough to provide a basis for the ongoing policy discussion relating, for example, to the UN Millennium Development Goals with regard to poverty reduction. We find that globalization is on average followed by lower poverty; however, only a small part of the effect is mediated via the growth channel.

The paper contributes to the literature in several ways. First, recent improvements in data availability allow us to construct a panel dataset with better coverage than previous studies. Our regressions include more than 100 countries, with poverty data averaged over four five-year periods, the first one being 1988 to 1992 .

Second, using the so-called KOF Index of Globalization, developed by Dreher (2006) and updated in Dreher et al. (2008), allows for an identification of the poverty effects of economic and social globalization separately. Moreover, for economic globalization, the index allows us to distinguish between trade flows and trade policies such as tariff rates. For social globalization, we separately analyze the poverty effects of information flows, personal contacts, and a measure of cultural proximity based on trade in books and the number of McDonald's restaurants and IKEA stores per capita.

Third, in addition to analyzing a panel with five-year averages, we also regress changes in globalization on subsequent changes in absolute poverty over a longer time period (12 years is the average duration in our sample), controlling for economic growth. This approach allows for an examination of how much of the effect of globalization on poverty is mediated by growth.

Fourth, by using interaction terms, we analyze if there are circumstances under which the relationship between globalization and poverty is particularly strong. For example, we examine if the association varies with level of democracy, country size of the informal sector and the quality of institutions. We also examine possible complementarities between economic and social globalization.

1 There are, however, some illuminating case studies of specific countries, including Verme (2010) for Kazakhstan, and Ravallion (2006) for China and Morocco. 
The results suggest a robust negative relationship between globalization and absolute poverty, which is consistent with the J-curve hypothesis, discussed by, for example, Agénor (2004), where increased globalization associates with short-run transition costs that may increase poverty, while globalization decreases poverty in the long run. In particular, information flows and more liberal trade restrictions robustly relate to lower poverty. When controlling for economic growth, the magnitude of the effect of globalization on poverty decreases only marginally, suggesting that higher growth is not the main mechanism through which globalization reduces poverty, a finding in line with some recent evidence (see for example Verme (2010), studying the development in Kazakhstan), but it is in stark contrast to standard references such as Dollar and Kraay (2004) and Bhagwati and Srinivasan (2002).

The article proceeds as follows. Section I introduces the literature on the relationship between types of globalization and growth, and discusses potential problems related to the measurement of poverty. Section II provides an analytical framework discussing the possible links from globalization to absolute poverty. Section III describes our data and empirical strategy, and presents baseline panel regression results. Section IV analyzes the role of potential mechanisms mediating the globalizationpoverty relationship, while section $\mathrm{V}$ examines the long-run association. The article closes with some concluding remarks on the implications of the findings.

\section{BACKGROUND}

Views on the relationship between globalization and poverty

Most studies of how globalization affects poverty focus on economic globalization, in particular trade openness. The standard approach, illustrated in figure $1 \mathrm{a}$, is to examine the effect on poverty by focusing on economic growth as a mediator, something Harrison and McMillan (2007) call "the orthodox view" (p. 124). A typical example is Dollar and Kraay (2004), who argue that trade is good for growth, and that there is no systematic relationship between changes in trade volumes and changes in the income distribution. Thus, they conclude, if trade or some other measure of economic openness increases growth rates, this translates into proportionate increases in the income of the poor. ${ }^{2}$

In the short run, however, globalization can affect absolute poverty regardless of its effect on growth. Growth occurs when average real income increases, but absolute poverty depends on how globalization affects the incomes of the poor. Theoretically, poverty may consequently decrease without growth or increase despite growth. The ambiguity of the relationship between growth and poverty reduction is not only a theoretical oddity: using data on 58 developing countries for the period 1980-1998, Kalwij and Verschoor (2007) find large regional variations in the capacity of growth to reduce absolute poverty. (The effect was found to be smallest in sub-Saharan Africa, and largest in the Middle East and North Africa region).

\footnotetext{
2 Another brief survey using the standard approach is Bhagwati and Srinivasan (2002). For more in-depth surveys of research regarding on economic globalization and poverty, see Agénor (2004) and Aisbett, et al. (2005).
} 
Figure $1 \mathrm{~b}$ presents an alternative, and to us preferred, view of the chain of mechanisms: globalization affects prices, incomes and information flows. Depending on how incomes, prices and behavior change, growth and/or poverty reduction may be the outcome.

FIGURE 1. Two views on the relations between globalization, growth and poverty

a

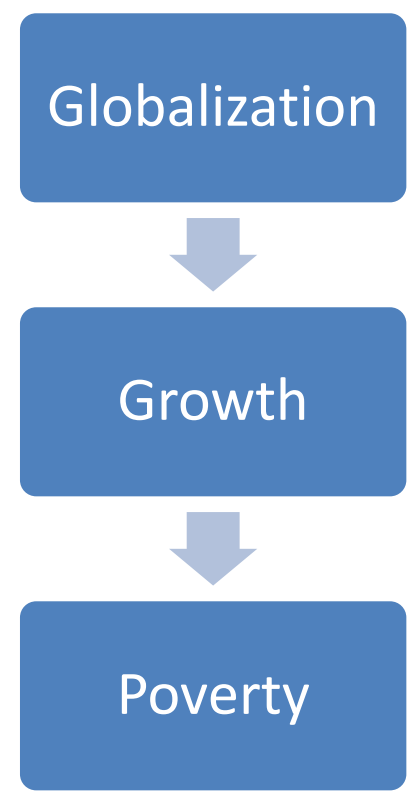

$\mathrm{b}$

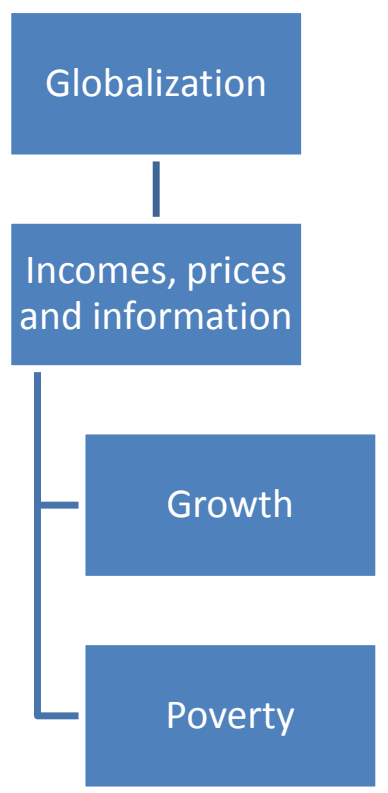

Our disapproval of the orthodox view is not new: Lundberg and Lyn (2003) argue that "the evolution of growth and inequality must surely be the outcome of similar processes" (p. 326). And Bourguignon (2004) notes that changes in poverty depend on growth in two ways: the initial income distribution and the change in the income distribution caused by growth.

Conclusions on the effect of globalization on poverty relying only on the chain from globalization to growth to poverty reduction are problematic also in light of the literature linking globalization to inequality: If globalization causes both growth and higher income dispersion, the effect on poverty is ambiguous. In fact, Bergh and Nilsson (2010), Milanovic and Squire (2006), and Lundberg and Lyn (2003) find evidence that trade or economic globalization tends to increase inequality. Bergh and Nilsson, however, note that the inequality effect is driven by the relationship in rich and middle-income countries, while Milanovic and Squire report that higher trade volume increases income inequality in poor countries only.

While these seemingly conflicting results may all be explained by differences in samples and the measurements used, the varying results nicely illustrate an essential point. To infer how globalization affects poverty, it is not enough to assume a constant income distribution such that a positive relationship 
between globalization and growth automatically implies less poverty. Instead, we will examine levels and first differences on how globalization relates to subsequent poverty.

In defense of the standard approach, it is worth mentioning that in the long run it is highly unlikely that growth occurs without a reduction of absolute poverty. From a policy perspective, however, it is still interesting to gain knowledge on whether the long run translates to 5 or 15 years, or even longer.

\section{Measuring poverty and globalization}

Measuring poverty involves a number of potential problems. For recent overviews of the debate and methodological choices involved, see Anand et al. (2010) and Deaton (2010).

First, the World Bank's poverty line set at one dollar (PPP adjusted) per day can be criticized for being too narrow. As the argument goes, poverty is a multidimensional concept that should not be reduced to a monetary measure of purchasing power.

Second, there is also a debate amongst those who accept the dollar-a-day measurement. Fundamentally, there is no obvious best way to calculate measures of absolute purchasing power that are comparable across both time and space when relative prices vary over time and between countries. Deaton (2010) describes how the level of headcount poverty and global Gini coefficients vary between versions of the World Development Indicators (WDI) and the Penn World Tables, but also notes that the trend over time is not sensitive to this data choice: the total percentage in absolute poverty and the population weighted Gini coefficient for GDP per capita decreased during the 1980s and the 1990s (a change largely driven by the development in China and India).

Third, the World Bank estimates rely heavily on household surveys, resulting in questionable comparability and low coverage for certain geographical regions, for example sub-Saharan Africa. Alternative estimates on mean income can be drawn from national accounts, but these tend to overestimate mean income, as tax revenues and corporate profits are included in GDP per capita.

Replying to critics, Ravallion (2010) argues that the practice of updating estimations and revising the poverty line when confronted with new data has led to fluctuations, but this should not lead one to question the methodology used: the World Bank estimates remain the best projections available for studying absolute poverty worldwide. Our preferred measure of absolute poverty is the headcount index calculated for a poverty line of one PPP dollar per day from the World Bank (2010).

The question of how to best measure economic globalization or economic openness has also been subjected to intense discussions. One of the most used measures of economic openness is the index introduced by Sachs and Warner (1995). This index, however, is binary and questions have been raised by, among others, Rodriguez and Rodrik (2000) with regard to what it actually measures. ${ }^{3}$ An important point brought up by Rodriguez and Rodrik (2000) is the distinction between trade flows (such as imports and exports) and trade policies (such as tariffs, taxes and regulations). Studies finding that trade flows are

\footnotetext{
${ }^{3}$ Responding to some of the critiques, Wacziarg and Welch (2008) update the Sachs-Warner index and find it to be significantly related to growth during the 1970s and the 1980s, but not during the 1990s. The same result appears in Rajan and Subramanian (2008).
} 
linked to growth are not sufficient to conclude that policies of economic openness lead to growth. More liberal trade restrictions need not necessarily lead to higher trade flows.

Globalization is, however, not only a question of economic openness. As discussed by Arribas et al. (2009), internationalization presents many facets because of the various types of interactions it involves, many of which may potentially affect poverty. Our preferred measure of globalization is the socalled KOF Index developed by Dreher (2006) and updated in Dreher et al. (2008). The index quantifies economic, social and political globalization, using principal components analysis, to construct an aggregate index that is comparable over time and between countries. In addition to allowing for a separation between three dimensions of globalization, economic globalization can be further broken down into trade flows and trade policies, and social globalization into information flows, personal contact and cultural proximity. The index is updated every year and available on the web. Details can be found in table 1 and table A1 in the Appendix. For further information, see Dreher et al. (2008).

This examination particularly focuses on the relationship between economic and social globalization and poverty, but leaves out a separate analysis of the political dimension of globalization. The indicators of political globalization are slightly hard to interpret, as there are no clear theoretical predictions as to how the indicators may affect poverty, and the problems of reverse causality may be severe. However, when using the aggregate index, political globalization is included. We do this in order to obtain results for globalization when measured the way intended by the creators of the KOF Index.

\section{POSSIBLE LINKS FROM GLOBALIZATION TO POVERTY}

Mainstream economic theory suggests several mechanisms through which economic openness may foster growth. Specialization, scale economies, competition, incentives for macro-economic stability, and innovation are all mechanisms likely to be important. More integration in the global economy may also increase the returns to higher education in poor countries, as described by Stark (2004), with positive longrun growth effects through human capital. Many of these effects are likely to require some time to also affect poverty, and as discussed before the poverty effect may be counteracted by increases in the income dispersion. Agénor (2004) describes several reasons for expecting economic globalization to decrease poverty in the long run but notes that due to various types of short-run costs, the short-term effect may, however, be an increase in absolute poverty. Such reasons include:

- Transition costs: As an economy opens, more and cheaper capital becomes available. When firms replace labor with capital in production, poverty may increase before laid-off workers find new employment. Increased competition following economic openness may also affect unemployment by forcing some domestic firms out of business.

- Shortage of human capital: If openness leads to the introduction of more advanced technologies, or more capital intense production, the full benefits may require more skilled labor than is initially available. 
- Better possibilities to work abroad are likely to increase the education premium, and as Stark (2004) describes, this likely affects the domestic stock of human capital but the mechanism is likely to work slowly.

- As discussed by Bhagwati and Srinivasan (2002), higher economic openness likely comes with a greater commitment to low inflation, which should foster growth in the long run and particularly assist the poor if they are vulnerable to inflation. The transition from high to low inflation may, however, be associated with higher unemployment in the short run.

- Globalization might affect government size and, for example, social spending, in turn affecting poverty. Two opposite mechanisms have been suggested: the race to the bottom hypothesis (Sinn, 1997), where open economies compete by lowering taxes for example, and the compensation hypothesis suggested by Rodrik (1998) and Lindbeck (1975), where open economies develop larger welfare states as an insurance institution.

In the presence of transition costs and the various time lags of the expected beneficial effects, there are strong reasons to expect an increase in globalization to have an inverted J-curve effect on absolute poverty.

Not all mechanisms suggest that economic globalization leads to lower poverty, even in the long run. For example, Kawachi and Wamala (2007) suggest that openness can lead to a faster and geographically broader spread of infectious diseases (such as HIV and the H5N1 avian influenza virus), which may increase poverty through lower productivity and labor supply. This adverse effect may well hit the poor relatively more, and thus serves as an example why openness may promote growth without decreasing poverty.

The KOF Index divides social globalization into information flows, personal contacts and cultural proximity, which are all likely to affect the functioning of markets, as well as the behavior of buyers and sellers on the market. In general, the functioning of markets is critically dependent on information flows. In less developed countries with high transaction costs and potentially large information asymmetries, there is a large potential gain in market efficiency from increased use of information and communications technologies (ICT). Both telecommunications and the Internet are powerful tools for information transfer and improve the functioning of markets in general. ${ }^{4}$ As noted by Aker and Mbiti (2010), the distribution of these efficiency gains among consumers, producers and firms is theoretically ambiguous. Lower search costs could benefit sellers in the short term if they make better use of spatial arbitrage opportunities, but as markets become more competitive, benefits will shift towards consumers as markets approach the law of one price (Aker and Mbiti, p. 216). There are also studies showing that rural telephony increases the prices farmers receive for their crops and the earnings from off-farm activities (e.g., Duncombe (1999) and Elbers and Lanjouw (2001)). Empirical evidence also suggests that telephone services can improve

\footnotetext{
4 A classic example of telecommunication is Hirschman (1967), showing how long distance telephone networks led to a credit market for coffee trade in Ethiopia. A more recent example is when the Indian company ITC launched a system called eChoupals, which enabled rural farmers to connect themselves and check crop prices online. This led to many of them bypassing local auction markets and selling crops directly to ITC for $\$ 6$ more per tonne than they previously received (Pralahad and Hammond, 2002).
} 
government services such as health care (ITU, 1998). Forestier et al. (2002) summarize a wide array of research on the effects of ICT on growth and inequality, and show that ICT in general is positively related to growth, but the effect on inequality is less clear. For any new information and communication technology, inequality is likely to increase in the short run, when only a small elite may access the technology. As more people get access, inequality falls. This reasoning applies to telephony, mobile phones and Internet access.

In general, information decreases transaction costs resulting in markets approaching the competitive equilibrium. Because transaction costs essentially work as a tax wedge, the effect of lowering such costs can be illustrated as shown in figure 2. When transaction costs are present, transactions between buyers and sellers will only take place if the difference between producers' reservation price and consumers' willingness to pay exceeds the transaction cost. In the figure, lowering transaction costs from t0 to t1 decreases the minimum difference between consumers' willingness to pay and producers' reservation price necessary for transactions to take place. Just like taxes, the burden of high transaction costs is shared between producers and consumers, and lowering transaction costs will increase output.

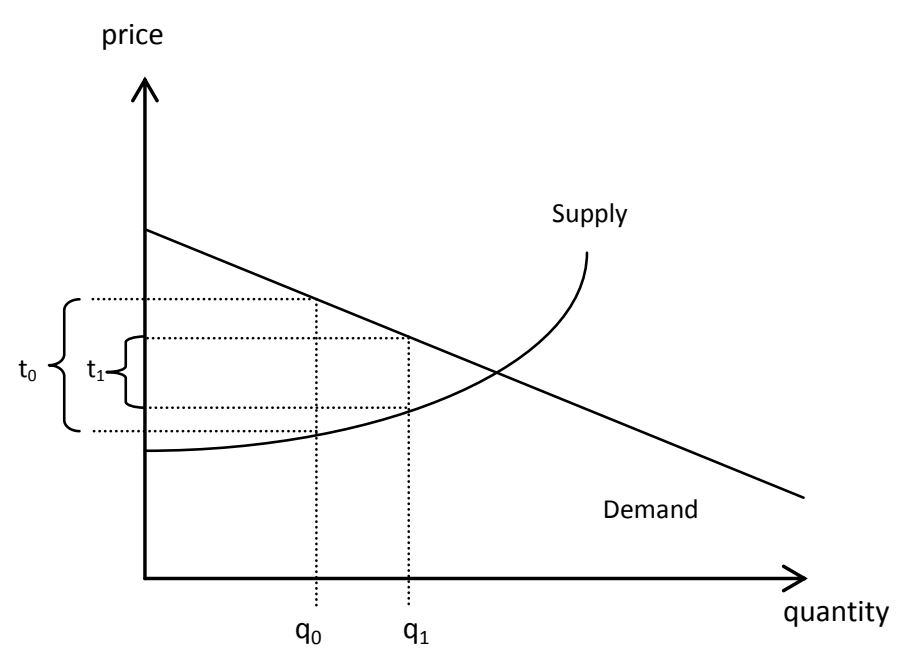

FIGURE 2: The welfare effect of lower transaction costs

In addition to information flows, social globalization comprises cross-border personal contacts. Outgoing telephone traffic likely affects economic outcomes through the transmission of information and knowledge, similar to many indicators of information flows. Other types of personal contacts such as tourism have less obvious consequences. Chao et al. (2004) note that tourism is good for development through terms of trade effect and resource flows; however, possible negative externalities of mass tourism might offset these effects. As noted by Kondoh (1999), there is an important difference between tourism 
and immigration (also included in the social globalization index though the percent of foreign population): both affect the demand side, but the latter also affects the supply side of the host economy. ${ }^{5}$

The third and final component of social globalization in the KOF Index is cultural proximity, measured by the number of McDonald's restaurants and IKEA stores per capita, as well as trade in books in percent of GDP. In developing countries, most of the index's variation is related to the opening of McDonald's restaurants. Indeed, McDonald's is often used as a symbol of globalization and has also given rise to the sociological term McDonaldization. ${ }^{6}$ The use of McDonald's restaurants in the index highlights the importance of mechanisms described by Medez and Popkin (2004): globalization may enhance access to non-traditional food, influencing dietary patterns throughout the developing world with possible implications for overweight/obesity.

Obviously, the opening of multinational companies like McDonald's and IKEA requires a certain level of economic globalization. IKEA, for example, relies heavily on cheap imports from developing countries in Asia. Therefore, it is only to be expected that the levels of economic and social globalization are positively correlated $(r=0.83)$, and in our main specifications they are not included simultaneously. It is of interest, however, to examine if the factors captured by social globalization add something that is not only a proxy for economic globalization. ${ }^{7}$ There may also be complementarities in globalization such that the effect of social globalization on poverty is bigger when economic globalization is high, or vice versa.

Following the above discussion, table 1 summarizes our measures of globalization and their expected effects on poverty. Few of the possible links between dimensions of globalization and absolute poverty are theoretically unambiguous, a situation that calls for empirical examination.

\footnotetext{
${ }^{5}$ Links between tourism, trade and growth have also been recently investigated by Katircioglu (2009) for the case of Cyprus.

${ }^{6}$ The term does, however, however not refer to the spread of McDonald's restaurants, but rather to "the process by which the principles of the fast-food restaurant are coming to dominate more and more sectors of American society, as well as the rest of the world." (Ritzer, 1996:293)

${ }^{7}$ Views differ as to whether to include the various dimensions of globalization simultaneously or not. Heckelman and Stroup (2005) argue that any summary index may result in a misspecification bias, and suggest also performing the analysis using the actual individual components. Dreher and Gaston (2008), however, argue that components of globalization should be regressed in the same specification, as the different components are highly correlated, to control for other globalization dimensions.
} 
TABLE 1. Indicators of economic and social globalization: expected effects on poverty

\begin{tabular}{|c|c|c|}
\hline $\begin{array}{l}\text { Type of } \\
\text { globalization }\end{array}$ & Economic & Social \\
\hline Measure & $\begin{array}{l}\text { Flows: Trade, investments and } \\
\text { international transfers (\% of } \\
\text { GDP). } \\
\text { Policies: Mean tariff rates, taxes, } \\
\text { import barriers, and capital } \\
\text { account restrictions. }\end{array}$ & 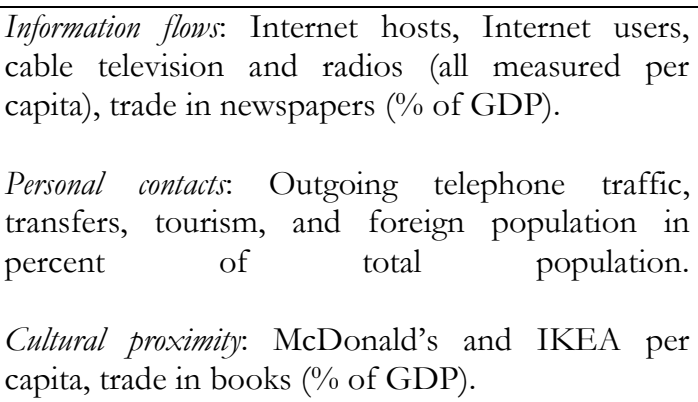 \\
\hline $\begin{array}{l}\text { Short-run } \\
\text { effects on }\end{array}$ & $\begin{array}{l}\text { Prices and wages via changes in } \\
\text { supply and demand. }\end{array}$ & Available information. Supply and demand. \\
\hline $\begin{array}{l}\text { Possible long- } \\
\text { run effects on }\end{array}$ & $\begin{array}{l}\text { Growth and innovation, human } \\
\text { capital (Stark, 2004). }\end{array}$ & $\begin{array}{l}\text { Social norms and lifestyle (Medez and Popkin } \\
\text { (2004), Yach et al. (2007)). }\end{array}$ \\
\hline $\begin{array}{l}\text { Expected } \\
\text { effect on } \\
\text { absolute } \\
\text { poverty }\end{array}$ & $\begin{array}{l}\text { Ambiguous in the short run, } \\
\text { negative in the long run. }\end{array}$ & Ambiguous both in the short and long run. \\
\hline
\end{tabular}




\section{DATA, EMPIRICAL STRATEGY AND BASELINE RESULTS}

Our dataset covers the 1988-2007 period, with data averaged over four five-year periods: 1988-1992, 1993-1997, 1998-2002, and 2003-2007. The panel is unbalanced but includes information for more than 100 countries, and the efficient sample consists of close to 300 observations meeting baseline specifications. An absolute majority of these observations refers to conditions in countries classified as low- or lower-middle-income countries with a 2008 GNI per capita of USD 3,855 or less. Table A2 in the Appendix presents descriptive statistics and sources for all variables used in the analysis, and table A3 in the Appendix presents details about the country sample.

The main dependent variable is the headcount index, defined as the percentage of the population in a particular country living on less than one dollar per day (PPP adjusted 1993). This measure comes from the Povcal database (World Bank, 2010) and is derived from household surveys. ${ }^{8}$ In the sensitivity analysis, we also use the poverty gap and the squared poverty gap, which account for the distribution of the poor as alternative dependent variables (taken from the same source). ${ }^{9}$

Our globalization measure is the KOF Index (Dreher et al., 2008), as described in section I. We use the index both as a composite measure $(K O F)$, in which the three dimensions of globalization are equally weighted together, and in a disaggregated format (KOF1 and KOF2). Moreover, we use the subcomponents for the economic and the social globalization index (flows and restrictions, and information flows, personal contact and cultural proximity, respectively). The index takes values between 0 and 100 with higher values indicating more globalization.

Because we expect an increase in globalization to have an inverted J-curve effect on poverty, we would ideally want to estimate a dynamic model that allows us to explore in detail the shape of such a Jcurve. Lack of data prevents us from using such models, but other methodological possibilities remain. One is to estimate the relationship in first differences during a period sufficiently long so that the effects of globalization are likely to be dominated by the long-run (poverty-decreasing) effects. We do this in section IV. Another possibility is to estimate a panel with globalization and poverty observed at regular intervals, allowing for non-linear effects to account for the inverted J-curve relation. A graphical explanation is given in figure 3, which illustrates the expected effect of a positive shock to globalization occurring at time t. If the inverted J-curve hypothesis is correct, and the interval is sufficiently long, we observe decreased poverty at $\mathrm{t}+1$.

Curve A illustrates a small positive globalization shock at time t. If a larger shock to globalization leads to larger transition costs, but also to greater long-run benefits, the inverted J-curve will look like curve $\mathrm{B}$, in which case poverty at $\mathrm{t}+1$ will be higher, despite eventually becoming lower.

\footnotetext{
8 There is a large discrepancy between national accounts and survey data estimates of consumption. A major source of controversy among researchers in the field relates to the question of what source of information should be used to accurately measure the level and change of poverty. For a thorough review of the advantages and limitations of survey-based measures, see Deaton (2001).

${ }^{9}$ In all but four cases-India, China, Indonesia, and Argentina-information on poverty outcomes refers to a national level. For these countries, we instead make use of poverty estimates referring to rural and urban areas. Our result and conclusions do not change when excluding these particular observations from the analysis.
} 
FIGURE 3. The effect on poverty of a positive shock to globalization at time $t$ in the presence of shortrun transition costs and long-run poverty-decreasing effects

Curve A: small increase in globalization at time t. Curve B: large increase in globalization at $\mathrm{t}$.

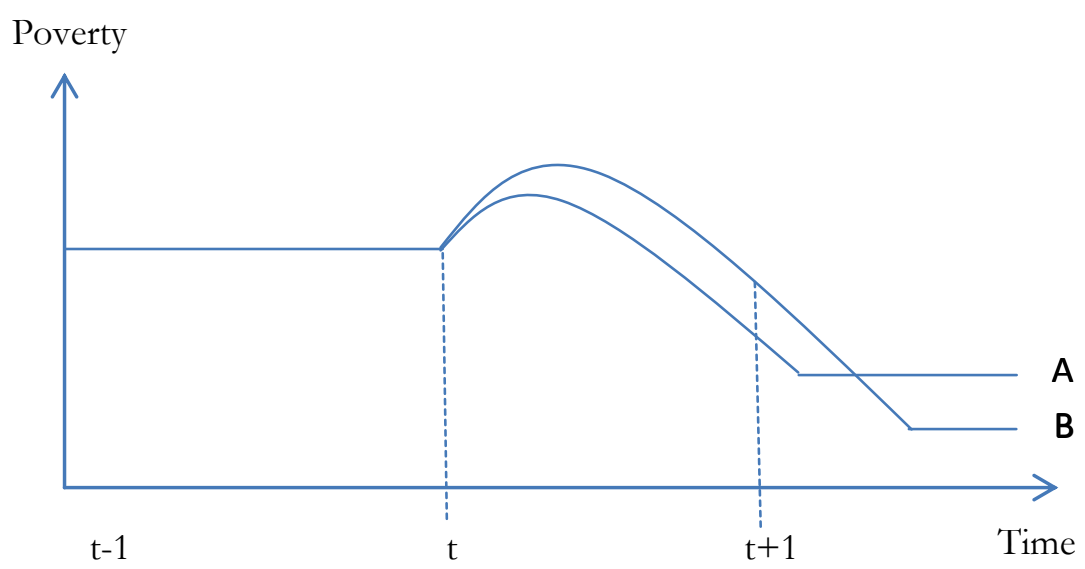

As shown in figure 3, if the observations are sufficiently far apart in time, we expect bigger increases in globalization to lead to larger decreases in poverty, and a linear model will do. However, if poverty observations occur at $t$ and $t+1$ as shown in the figure, we will actually observe higher poverty at $t+1$ for the larger globalization shock (curve B) compared to the smaller shock (curve A). In this case, the empirical patterns consistent with the inverted J-curve theory will be a negative coefficient on the linear term and a positive coefficient on the squared term in a regression of poverty on globalization with time and country-fixed effects and poverty observed five years after globalization. In a first difference regression using the longest durations available in the data, we expect a negative relation between changes in globalization and changes in poverty (assuming that the period is long enough for the long-run effect to dominate). Needless to say, the long-run, poverty-decreasing effects from globalization may be small and/or take more than 15 years to materialize, in which case we will find that globalization increases poverty, or that globalization does not matter at all.

We first formulate the following empirical model, where countries are represented by $i$ and time by $t$ :

$$
\text { Poverty }_{i t}=\alpha+\text { Glob }_{i t-1} \beta_{1}+\text { Glob }_{i t-1}^{2} \beta_{2}+X_{i t} \beta_{3}+\delta_{i}+\rho_{t}+\varepsilon_{i t}
$$

In equation (1), Glob is a vector for different types of globalization, and because the impact of globalization on poverty is unlikely to be instant, these variables are lagged. For example, average globalization in 1983-1987 is used to explain average poverty in 1988-1992.10

$X$ is a vector that includes the additional covariates presented above, which are either classified as potential mediators through which globalization influences poverty or as exogenous factors affecting poverty

\footnotetext{
${ }^{10}$ Lagging globalization also reduces the bias following from potentially reverse causality between globalization and poverty. One reason for expecting a reverse causality is that donor programs targeting poor countries have recently often recommended economic openness as a main policy.
} 
but not themselves influenced by globalization. $\delta_{i}$ corresponds to a country-fixed effect that captures stable differences in poverty between countries, while $\rho_{t}$ is a period-fixed effect capturing the influence of shocks that affect poverty in multiple countries at the same time. $\varepsilon_{i t}$ is an error term assumed to be normally distributed. ${ }^{11}$

To economize on data, we begin by estimating a relatively parsimonious baseline, controlling only for country log real GDP per capita (PPP adjusted) from the World Bank (2010). To maximize comparability across specifications, including the same indicator of globalization, we let the sample contain the same countries. The number of observations might, however, vary across index-specific estimations. ${ }^{12}$ Table 2 presents baseline results using panel regressions.

TABLE 2. Baseline panel regression results. Dependent variable: Headcount index

\begin{tabular}{|c|c|c|c|c|c|c|}
\hline & $(1)$ & $(2)$ & (3) & (4) & (5) & $(6)$ \\
\hline $\mathrm{KOF}(\mathrm{t}-1)$ & $\begin{array}{c}-1.48^{* * *} \\
{[0.40]}\end{array}$ & $\begin{array}{c}-1.23 * * * \\
{[0.40]}\end{array}$ & & & & \\
\hline $\operatorname{KOF}(\mathrm{t}-1)^{\wedge} 2$ & $\begin{array}{c}0.01 * * * \\
{[0.00]}\end{array}$ & $\begin{array}{c}0.01 * * * \\
{[0.00]}\end{array}$ & & & & \\
\hline KOF1 (t-1) & & & $\begin{array}{c}-0.85^{* * *} \\
{[0.25]}\end{array}$ & $\begin{array}{c}-0.83^{* * *} \\
{[0.25]}\end{array}$ & & \\
\hline $\mathrm{KOF} 1(\mathrm{t}-1)^{\wedge} 2$ & & & $\begin{array}{c}0.01 * * * \\
{[0.00]}\end{array}$ & $\begin{array}{c}0.01 * * * \\
{[0.00]}\end{array}$ & & \\
\hline $\mathrm{KOF} 2(\mathrm{t}-1)$ & & & & & $\begin{array}{c}-0.98^{* * *} \\
{[0.27]}\end{array}$ & $\begin{array}{c}-0.81 * * * \\
{[0.27]}\end{array}$ \\
\hline $\mathrm{KOF} 2(\mathrm{t}-1)^{\wedge} 2$ & & & & & $\begin{array}{c}0.01^{* * *} \\
{[0.00]}\end{array}$ & $\begin{array}{c}0.01 * * * \\
{[0.00]}\end{array}$ \\
\hline GDP per capita ( $\mathrm{t}$ ) & & $\begin{array}{c}-8.16^{*} \\
{[4.51]}\end{array}$ & & $\begin{array}{c}-10.06^{* *} \\
{[4.10]}\end{array}$ & & $\begin{array}{c}-11.43^{* * *} \\
{[4.25]}\end{array}$ \\
\hline Constant & $\begin{array}{c}59.42^{* * *} \\
{[12.45]}\end{array}$ & $\begin{array}{c}116.12^{* * *} \\
{[34.27]} \\
\end{array}$ & $\begin{array}{c}43.53^{* * *} \\
{[6.98]}\end{array}$ & $\begin{array}{c}122.03 * * * \\
{[31.79]} \\
\end{array}$ & $\begin{array}{c}43.68^{* * *} \\
{[6.37]}\end{array}$ & $\begin{array}{c}129.34 * * * \\
{[33.86]}\end{array}$ \\
\hline R-squared (within) & 0.23 & 0.25 & 0.20 & 0.23 & 0.23 & 0.27 \\
\hline Observations & 301 & 301 & 294 & 294 & 301 & 301 \\
\hline Number of countries & 106 & 106 & 101 & 101 & 105 & 105 \\
\hline
\end{tabular}

Robust standard errors in brackets.

$*$, **, and *** denote statistical significance at the $10 \%, 5 \%$, and $1 \%$ levels, respectively.

Looking first at the aggregated index (columns 1 to 2), globalization negatively associates with absolute poverty but with decreasing marginal effect, which is consistent with the inverted J-curve hypothesis. Note

\footnotetext{
11 The null hypothesis of no country effects is rejected in all estimations. Consequently, a pooled regression model for analyzing the association between globalization and poverty is not appropriate. Moreover, using a Hausman test, the random-effect model is rejected against the fixed-effect model. Time dummies are jointly significant in a majority of baseline specifications, suggesting they should be included in the model.

${ }^{12}$ Notably, results do not change when restricting the sample to the very same observations across all specifications. In this case, the sample consists of 283 observations.
} 
that the aggregate index includes political globalization that we do not analyze separately. ${ }^{13}$ Results for the different types of globalization (columns 3 to 6 ) suggest that the poverty-decreasing effect holds for both economic and social globalization. As expected, the size of the association decreases when controlling for income, but only marginally. This suggests that globalization tends to decrease poverty, but not mainly via the income channel—at least in the short run captured by our panel.

Examining what indicators of economic and social globalization drive the negative association with poverty in table 3 gives some clear and interesting results. Including trade flows and trade restrictions separately and together (column 1 to 6 ) suggests that the significant coefficient on economic globalization comes from restrictions rather than from flows. ${ }^{14}$ A similar exercise for social globalization (columns 7 to 14) points to the importance of information flows for decreasing poverty, while cultural proximity actually seems to have a small poverty-increasing effect when all components of social globalization are included simultaneously.

\footnotetext{
${ }^{13}$ Examining the effect of political globalization separately reveals a poverty-increasing effect, which is not robust and appears to be driven by less democratic countries.

${ }^{14}$ Note that restrictions and flows are not very highly correlated $(\mathrm{r}=0.51)$ because exports and imports tend to be higher as a share of GDP in smaller countries.
} 
TABLE 3. Baseline panel regression results cont. Dependent variable: Headcount index

\begin{tabular}{|c|c|c|c|c|c|c|c|c|c|c|c|c|c|c|}
\hline & $(1)$ & $(2)$ & (3) & (4) & $(5)$ & $(6)$ & $(7)$ & $(8)$ & (9) & $(10)$ & $(11)$ & $(12)$ & (13) & $(14)$ \\
\hline \multirow[t]{2}{*}{ Trade flows (t-1) } & $-0.33^{*}$ & -0.26 & & & -0.25 & -0.17 & & & & & & & & \\
\hline & {$[0.17]$} & {$[0.17]$} & & & {$[0.19]$} & {$[0.17]$} & & & & & & & & \\
\hline \multirow[t]{2}{*}{ Trade flows $(\mathrm{t}-1)^{\wedge} 2$} & $0.00^{* *}$ & $0.00^{*}$ & & & 0.00 & 0.00 & & & & & & & & \\
\hline & {$[0.00]$} & {$[0.00]$} & & & {$[0.00]$} & {$[0.00]$} & & & & & & & & \\
\hline \multirow[t]{2}{*}{ Restrictions (t-1) } & & & $-0.54 * *$ & $-0.65^{* * *}$ & $-0.55^{* *}$ & $-0.61 * *$ & & & & & & & & \\
\hline & & & {$[0.23]$} & {$[0.24]$} & {$[0.26]$} & {$[0.27]$} & & & & & & & & \\
\hline \multirow[t]{2}{*}{ Restrictions $(\mathrm{t}-1)^{\wedge} 2$} & & & $0.01 * * *$ & $0.01 * * *$ & $0.00 * *$ & $0.01^{* *}$ & & & & & & & & \\
\hline & & & {$[0.00]$} & {$[0.00]$} & {$[0.00]$} & {$[0.00]$} & & & & & & & & \\
\hline \multirow[t]{2}{*}{ Personal contact $(\mathrm{t}-1)$} & & & & & & & $-1.16^{*}$ & -0.75 & & & & & -0.47 & -0.07 \\
\hline & & & & & & & {$[0.66]$} & {$[0.63]$} & & & & & {$[0.49]$} & {$[0.49]$} \\
\hline \multirow[t]{2}{*}{ Personal contact $(\mathrm{t}-1)^{\wedge} 2$} & & & & & & & $0.01 *$ & 0.01 & & & & & 0.01 & 0.00 \\
\hline & & & & & & & {$[0.01]$} & {$[0.01]$} & & & & & {$[0.01]$} & {$[0.01]$} \\
\hline \multirow[t]{2}{*}{ Information flows (t-1) } & & & & & & & & & $-0.85^{* * *}$ & $-0.81 * * *$ & & & $-0.92 * * *$ & $-1.00^{* * *}$ \\
\hline & & & & & & & & & {$[0.18]$} & [0.19] & & & {$[0.17]$} & [0.19] \\
\hline \multirow[t]{2}{*}{ Information flows $(\mathrm{t}-1)^{\wedge}$ : } & & & & & & & & & $0.01 * * *$ & $0.01 * * *$ & & & $0.01 * * *$ & $0.01 * * *$ \\
\hline & & & & & & & & & {$[0.00]$} & {$[0.00]$} & & & {$[0.00]$} & {$[0.00]$} \\
\hline \multirow[t]{2}{*}{ Cultural proximity (t-1) } & & & & & & & & & & & -0.13 & -0.07 & 0.11 & $0.18^{* *}$ \\
\hline & & & & & & & & & & & {$[0.13]$} & {$[0.11]$} & {$[0.10]$} & {$[0.09]$} \\
\hline \multirow[t]{2}{*}{ Cultural proximity $(\mathrm{t}-1)^{\wedge}$} & & & & & & & & & & & 0.00 & 0.00 & -0.00 & $-0.00 * *$ \\
\hline & & & & & & & & & & & {$[0.00]$} & {$[0.00]$} & {$[0.00]$} & {$[0.00]$} \\
\hline \multirow[t]{2}{*}{ GDP per capita ( $t$ ) } & & $-9.47 * *$ & & $-11.26^{* * *}$ & & $-10.06^{* *}$ & & $-12.64 * * *$ & & $-14.42^{* * *}$ & & $-9.29 * *$ & & $-11.83^{* * *}$ \\
\hline & & {$[4.40]$} & & [4.19] & & [4.39] & & [4.51] & & [4.38] & & {$[4.43]$} & & [4.09] \\
\hline \multirow[t]{2}{*}{ Constant } & $31.19^{* * *}$ & $103.91 * * *$ & $30.65^{* * *}$ & $126.28^{* * *}$ & $41.22^{* * *}$ & $120.62 * * *$ & $40.72 * * *$ & $134.58^{* * *}$ & $44.03 * * *$ & $156.04 * * *$ & $16.99 * * *$ & $93.18^{* *}$ & $50.21 * * *$ & $136.28^{* * *}$ \\
\hline & [4.58] & [33.62] & [7.80] & {$[36.22]$} & [7.50] & [34.88] & {$[13.48]$} & [38.14] & [4.21] & [35.68] & {$[2.60]$} & {$[36.87]$} & [11.64] & {$[35.83]$} \\
\hline$\overline{R \text {-squared (within) }}$ & 0.11 & 0.14 & 0.19 & 0.23 & 0.17 & 0.21 & 0.12 & 0.16 & 0.19 & 0.24 & 0.15 & 0.18 & 0.26 & 0.31 \\
\hline Observations & 284 & 284 & 277 & 277 & 255 & 255 & 312 & 312 & 318 & 318 & 253 & 253 & 249 & 249 \\
\hline Number of countries & 99 & 99 & 95 & 95 & 86 & 86 & 109 & 109 & 114 & 114 & 84 & 84 & 81 & 81 \\
\hline
\end{tabular}

Robust standard errors in brackets.

$*$,**, and ${ }^{* * *}$ denote statistical significance at the $10 \%, 5 \%$, and $1 \%$ levels, respectively. 


\section{TESTING FOR MECHANISMS AND ROBUSTNESS}

To gain knowledge about potential mediators (factors through which globalization affects poverty) we add a number of control variables to the baseline regression as shown in table 4 .

TABLE 4. Description of control variables

\begin{tabular}{|l|l|}
\hline Variable & Expected effect \\
\hline $\begin{array}{l}\text { Average level of education in the } \\
\text { population over 15 years old }\end{array}$ & $\begin{array}{l}\text { Negative, i.e. education should } \\
\text { decrease poverty }\end{array}$ \\
\hline $\begin{array}{l}\text { Share of the population residing } \\
\text { in urban areas }\end{array}$ & Ambiguous \\
\hline $\begin{array}{l}\text { Government final consumption } \\
\text { expenditure (percent of GDP) }\end{array}$ & Ambiguous \\
\hline Inflation rate & $\begin{array}{l}\text { Positive, i.e. higher inflation } \\
\text { should increase poverty }\end{array}$ \\
\hline
\end{tabular}

While an expected negative effect of education on poverty is uncontroversial, there are different views on the poverty consequences of urbanization. As noted by Leon (2008), the positive and progressive aspects of cities often recognized by historians and economists contrast with the more pessimistic tone of the epidemiological and public health literature, which according to Leon can be traced back to Snow (1855), who described the effects of cholera spreading in London during the 1840s. The newer, more optimistic view is summarized by Whiting and Unwin (2009), who note that, "Greater urbanization in low income countries is an essential component of economic development and from this perspective is both inevitable and desirable" (p. 1737), and also clearly evident in the World Development Report 2009 (World Bank, 2009).

With regard to government consumption, there are several reasons to expect that states with larger welfare systems have lower poverty rates, but higher government expenditure does not necessarily imply a larger welfare state. For example, many developing countries allocate relatively large shares of public expenditures to defense activities, and as shown by Mosley and Suleiman (2007) such expenditures seem to hurt, not support, the poor. Inflation is generally assumed to be harmful to the poor, whose assets are typically less protected against inflation. Unanticipated inflation may also lead to resource misallocation in an attempt to mitigate the uncertainty of future price levels, in turn prohibiting possibilities of progressive redistribution, as described by Fischer and Modigliani (1978).

Table 5 summarizes the results from regressions including control variables. To facilitate comparison and interpretations, the table starts by repeating the baseline estimates. Next, we control for government consumption as a share of GDP. This variable is not significant and does not change other coefficients by much at all, suggesting that government size is not an important mechanism for poverty reduction. 
Urbanization, on the other hand, turns out to be negatively related to poverty, supporting the newer rather than the older view as described earlier, but the variable inclusion does not change the globalization coefficients. Perhaps more surprisingly, education seems to be unrelated to poverty. Inflation, interestingly, turns out to associate with less poverty. This unexpected result may in part be explained by the fact that many poor consume self-grown crops and also sell part of the crops at market prices. In this way, they are protected against the adverse effects of inflation. Finally, including all the above control variables in the same specification changes little except for small reductions in the size of the globalization coefficients.

Finally, we examine if the relationship between globalization and poverty depends on the level of democracy using the Polity IV index by Marshall and Jaggers (2009), which ranges from 10 to 10 with higher values indicating more democratic regimes. ${ }^{17}$ Including only observations with a Polity IV score of at least 7 in the regression (there are 115 such observations from 50 countries, with an average Polity IV score of 8.26), results in a slightly larger coefficient on the aggregated globalization index, and also marks social globalization insignificant. The insignificance of social globalization masks, however, a negative effect of information flows and a positive effect of cultural proximity, similarly to the full sample. For economic globalization, the effect seems driven by restrictions, again similarly to the full sample.

Running a separate regression on the remaining 186 observations (coming from 82 countries with an average Polity IV score of 2.76) reveals that the negative coefficient on economic globalization in less democratic countries is driven by trade flows rather than restrictions, contrary to the results using the full sample.

\footnotetext{
17 The index aims to capture three elements of democracy: (i) the presence of institutions and procedures enabling citizens to express their preferences for policies and leaders; (ii) the existence of effective constraints on the exercise of power by the executive; and (iii) guarantee of civil liberties to participate in the political process.
} 
TABLE 5. Exploring the mechanisms from globalization to poverty reduction

\begin{tabular}{|c|c|c|c|c|c|c|c|c|c|}
\hline Variation & Composite & $\mathrm{OF}$ index & Significant $\alpha$ & onents & & & & & Comments \\
\hline Baseline model & $\begin{array}{l}-1.23^{* * *} \\
0.01 * * *\end{array}$ & $\begin{array}{l}{[0.40]} \\
{[0.00]}\end{array}$ & $\begin{array}{l}\text { KOF1 (t-1) } \\
\operatorname{KOF} 2(t-1)\end{array}$ & $\begin{array}{l}-0.83^{* * *} \\
0.01^{* * *} \\
-0.81^{* * *} \\
0.01^{* * *}\end{array}$ & $\begin{array}{l}{[0.25]} \\
{[0.00]} \\
{[0.27]} \\
{[0.00]}\end{array}$ & $\begin{array}{l}\text { Restrictions ( }(-1) \\
\text { Information flows ( } t-1) \\
\text { Cultural proximity (t-1) }\end{array}$ & $\begin{array}{c}-0.61^{* *} \\
0.01^{* *} \\
-1.00^{* * *} \\
0.01^{* * *} \\
0.18^{* * *} \\
-0.00^{* *}\end{array}$ & $\begin{array}{l}{[0.27]} \\
{[0.00]} \\
{[0.19]} \\
{[0.00]} \\
{[0.09]} \\
{[0.00]}\end{array}$ & $\begin{array}{l}\text { Baseline estimates } \\
\text { Corresponds to the results in Table } 1 \text { and Table } 2\end{array}$ \\
\hline $\begin{array}{l}\text { Controlling for } \\
\text { govermment consumption } \\
\text { (\% of GDP) }\end{array}$ & $\begin{array}{l}-1.22^{* * *} \\
0.01^{* * *}\end{array}$ & $\begin{array}{l}{[0.40]} \\
{[0.00]}\end{array}$ & $\begin{array}{l}\text { KOF1 (t-1) } \\
\text { KOF2 }(t-1)\end{array}$ & $\begin{array}{l}-0.84^{* * *} \\
0.01^{* * *} \\
-0.73^{* *} \\
0.01^{* * *}\end{array}$ & $\begin{array}{l}{[0.26]} \\
{[0.00]} \\
{[0.28]} \\
{[0.00]}\end{array}$ & $\begin{array}{l}\text { Restricions ( } t-1) \\
\text { Information flows }(t-1) \\
\text { Cultural proximity }(t-1)\end{array}$ & $\begin{array}{c}-0.80^{* * *} \\
0.01^{* * *} \\
-1.00^{* * *} \\
0.01^{* * *} \\
0.17^{*} \\
-0.00^{* *}\end{array}$ & $\begin{array}{l}{[0.25]} \\
{[0.00]} \\
{[0.20]} \\
{[0.00]} \\
{[0.09]} \\
{[0.00]}\end{array}$ & $\begin{array}{l}\text { Government consumption } \\
\text { negative and insignificant }\end{array}$ \\
\hline $\begin{array}{l}\text { Controlling for } \\
\text { urban population } \\
\text { (\% of total) }\end{array}$ & $\begin{array}{l}-1.21^{* * *} \\
0.01^{* * * *}\end{array}$ & $\begin{array}{l}{[0.39]} \\
{[0.00]}\end{array}$ & $\begin{array}{l}\text { KOF1 (t-1) } \\
\text { KOF2 (t-1) }\end{array}$ & $\begin{array}{l}-0.77^{* * * *} \\
0.01^{* * * *} \\
-0.74^{* * * *} \\
0.01^{* * * *}\end{array}$ & $\begin{array}{l}{[0.25]} \\
{[0.00]} \\
{[0.25]} \\
{[0.00]}\end{array}$ & $\begin{array}{l}\text { Restrictions (t-1) } \\
\text { Information flows (t-1) } \\
\text { Cultural proximity (t-1) }\end{array}$ & $\begin{array}{c}-0.56^{* *} \\
0.01^{* *} \\
-0.95^{* * *} \\
0.01^{* * *} \\
0.18^{*} \\
-0.00^{* * *}\end{array}$ & $\begin{array}{l}{[0.27]} \\
{[0.00]} \\
{[0.18]} \\
{[0.00]} \\
{[0.09]} \\
{[0.00]}\end{array}$ & $\begin{array}{l}\text { Urban population } \\
\text { negative and significant }\end{array}$ \\
\hline Controlling for education & $\begin{array}{l}-1.18^{* * *} \\
0.01 * * *\end{array}$ & $\begin{array}{l}{[0.43]} \\
{[0.00]}\end{array}$ & $\begin{array}{l}\text { KOF1 (t-1) } \\
\text { KOF2 }(t-1)\end{array}$ & $\begin{array}{c}-0.83^{* * *} \\
0.01^{* * *} \\
-0.72^{* * *} \\
0.01^{* * *}\end{array}$ & $\begin{array}{l}{[0.27]} \\
{[0.00]} \\
{[0.26]} \\
{[0.00]}\end{array}$ & $\begin{array}{l}\text { Restrictions ( }(-1) \\
\text { Information flows ( } t-1) \\
\text { Cultural proximity }(t-1)\end{array}$ & $\begin{array}{c}-0.59^{* *} \\
0.01^{* *} \\
-1.04^{* * *} \\
0.01^{* * *} \\
0.20^{* *} \\
-0.00^{* *}\end{array}$ & $\begin{array}{l}{[0.28]} \\
{[0.00]} \\
{[0.21]} \\
{[0.00]} \\
{[0.09]} \\
{[0.00]}\end{array}$ & Education insignificant in all estimations \\
\hline Controlling for inflation & $\begin{array}{l}-1.33^{* * *} \\
0.01^{* * *}\end{array}$ & $\begin{array}{l}{[0.40]} \\
{[0.00]}\end{array}$ & $\begin{array}{l}\text { KOF1 (t-1) } \\
\text { KOF2 }(t-1)\end{array}$ & $\begin{array}{l}-0.69^{* * *} \\
0.01^{* * *} \\
-0.84^{* * *} \\
0.01^{* * *}\end{array}$ & $\begin{array}{l}{[0.24]} \\
{[0.00]} \\
{[0.25]} \\
{[0.00]}\end{array}$ & $\begin{array}{l}\text { Information flows }(t-1) \\
\text { Cultural proximity }(t-1)\end{array}$ & $\begin{array}{c}-0.92^{* * *} \\
0.01^{* * *} \\
0.19^{* *} \\
-0.00^{* *}\end{array}$ & $\begin{array}{l}{[0.19]} \\
{[0.00]} \\
{[0.09]} \\
{[0.00]}\end{array}$ & Inflation negative and significant \\
\hline $\begin{array}{l}\text { Induding all potential mechanisms } \\
\text { in the same specification }\end{array}$ & $\begin{array}{l}-1.22^{* * *} \\
0.01^{* * * *}\end{array}$ & $\begin{array}{l}{[0.41]} \\
{[0.00]}\end{array}$ & $\begin{array}{l}\text { KOF1 (t-1) } \\
\text { KOF2 }(t-1)\end{array}$ & $\begin{array}{l}-0.65^{* *} \\
0.01^{* * * *} \\
-0.64^{* * * *} \\
0.01^{* * * *}\end{array}$ & $\begin{array}{l}{[0.26]} \\
{[0.00]} \\
{[0.23]} \\
{[0.00]}\end{array}$ & $\begin{array}{l}\text { Restrictions ( } \mathrm{t}-1) \\
\text { Information flows (t-1) } \\
\text { Cultural proximity }(\mathrm{t}-1)\end{array}$ & $\begin{array}{c}-0.55^{* *} \\
0.01^{* *} \\
-0.94^{* * *} \\
0.01^{* * *} \\
0.19^{*} \\
-0.00^{* * *}\end{array}$ & $\begin{array}{l}{[0.27]} \\
{[0.00]} \\
{[0.20]} \\
{[0.00]} \\
{[0.09]} \\
{[0.00]}\end{array}$ & \\
\hline
\end{tabular}


TABLE 5. Exploring the mechanisms from globalization to poverty reduction, cont.

\begin{tabular}{|c|c|c|c|c|c|c|c|c|c|}
\hline $\begin{array}{l}\text { Induding economic and social } \\
\text { globalization in the same specification }\end{array}$ & & & KOF2 $(t-1)$ & $\begin{array}{l}-0.79 * * \\
0.01 * * *\end{array}$ & $\begin{array}{l}{[0.34]} \\
{[0.00]}\end{array}$ & & & & \\
\hline $\begin{array}{l}\text { Interation term between } \\
\text { economic and sodal globalization }\end{array}$ & & & $\operatorname{KOF} 1(\mathrm{t}-1) * \operatorname{KOF} 2(\mathrm{t}-1)$ & -0.012 & {$[0.01]$} & & & & \\
\hline $\begin{array}{l}\text { Only induding } \\
\text { observations for democrades }\end{array}$ & $\begin{array}{l}-1.42^{* *} \\
0.01^{* *}\end{array}$ & $\begin{array}{l}{[0.62]} \\
{[0.00]}\end{array}$ & KOF1 (t-1) & $\begin{array}{l}-0.64^{*} \\
0.01^{* *}\end{array}$ & $\begin{array}{l}{[0.34]} \\
{[0.00]}\end{array}$ & $\begin{array}{l}\text { Restricions ( } t-1) \\
\text { Information flows ( } t-1) \\
\text { Cultural proximity }(t-1)\end{array}$ & $\begin{array}{c}-0.60^{* *} \\
0.01^{* * *} \\
-0.67^{* * *} \\
0.00^{* * *} \\
0.23^{*} \\
-0.00^{* *}\end{array}$ & $\begin{array}{l}{[0.27]} \\
{[0.00]} \\
{[0.20]} \\
{[0.00]} \\
{[0.12]} \\
{[0.00]}\end{array}$ & $\begin{array}{l}\text { Sample consists of observations } \\
\text { with a Polity IV index } \\
\text { equal or larger than } 7\end{array}$ \\
\hline $\begin{array}{l}\text { Only induding } \\
\text { observations for non-democracies }\end{array}$ & $\begin{array}{l}-0.97^{*} \\
0.01^{* *}\end{array}$ & $\begin{array}{l}{[0.55]} \\
{[0.00]}\end{array}$ & $\begin{array}{l}\text { KOF1 (t-1) } \\
\text { KOF2 (t-1) }\end{array}$ & $\begin{array}{l}-0.86^{* *} \\
0.01^{* * *} \\
-1.00^{* *} \\
0.01^{* * * *}\end{array}$ & $\begin{array}{l}{[0.43]} \\
{[0.01]} \\
{[0.45]} \\
{[0.00]}\end{array}$ & $\begin{array}{l}\text { Trade flows (t-1) } \\
\text { Information flows (t-1) }\end{array}$ & $\begin{array}{c}-0.51^{*} \\
0.00 \\
-0.71^{* *} \\
0.01^{* * *}\end{array}$ & $\begin{array}{l}{[0.30]} \\
{[0.00]} \\
{[0.30]} \\
{[0.00]}\end{array}$ & $\begin{array}{l}\text { Sample consists of observations } \\
\text { with a Polity IV index lower than } 7\end{array}$ \\
\hline
\end{tabular}

Robust standerd errors in brackets.

$*+$, and ${ }^{* * *}$ denote statistical significance at the $10 \%, 5 \%$, and $1 \%$ levels, respectively. 
Sindzingre (2005) suggests variability in the impact of globalization on poverty outcomes may stem from discontinuities and particularly emphasize institutions as a critical factor for the impact of globalization on the poor. Following this argument, it seems relevant to analyze if there are circumstances when the relationship of interest is particularly strong. Table 6 presents results for estimations, including interaction terms between dimensions of globalization and various factors. While the globalization-poverty association does not significantly vary with the quality of institutions or level of democracy, globalization seems particularly poverty reducing in countries with a large informal sector. Results further suggest that globalization is beneficial for the rural poor. We also examine possible complementarities between economic and social globalization but do not find any significant interaction effect.

TABLE 6. Interaction effects

\begin{tabular}{lcccl}
\hline & KOF(t-1) & KOF1(t-1) & KOF2(t-1) & Comments \\
\hline \hline Urban population (t-1) & $0.012^{* * *}$ & $0.009^{* * *}$ & $0.010^{* * *}$ & Positive significant interaction with trade flows \\
& {$[0.003]$} & {$[0.003]$} & {$[0.003]$} & \\
Size of formal sector (t-1) & $0.014^{* * *}$ & $0.012^{* *}$ & $0.018^{* *}$ & Limitied data on size of formal sector \\
& {$[0.005]$} & {$[0.005]$} & {$[0.007]$} & $\begin{array}{l}\text { - results from pooled regressions (incl. regional dummies) } \\
\text { Positive significant interactions with restristions \& cultural proximity }\end{array}$ \\
Rule of Law (t-1) & -0.008 & 0.007 & -0.003 & Negative significant interaction with information flows \\
& {$[0.005]$} & {$[0.005]$} & {$[0.004]$} & \\
Level of democracy (t-1) & 0.011 & 0.007 & 0.009 & Negative significant interaction with cultural proximity \\
& {$[0.013]$} & {$[0.010]$} & {$[0.010]$} & \\
Level of education (t-1) & 0.005 & 0.004 & 0.002 & Positive significant interaction with trade flows \\
& {$[0.004]$} & {$[0.004]$} & {$[0.003]$} & \\
Level of corruption (t-1) & -0.001 & 0.006 & 0.002 & Positive significant interaction with cultural proximity \\
& {$[0.004]$} & {$[0.004]$} & {$[0.004]$} & \\
Government expenditure (t-1) & 0.016 & 0.007 & 0.013 & Positive significant interaction with cultural proximity \\
& {$[0.012]$} & {$[0.011]$} & {$[0.011]$} & \\
\hline Robust standard errors in brackets. & & &
\end{tabular}

To further check the robustness of our baseline findings using panel regressions, table A4 in the Appendix presents the results from the following sensitivity tests: changing the specification to a random effects model, using globalization in period $\mathrm{t}$ rather than $\mathrm{t}-1$, excluding observations with extreme values of globalization and poverty, using alternative measures of poverty, and excluding various geographical regions. Overall baseline results are very robust to various changes, suggesting that globalization is good for the poor. In particular, more liberal trade restrictions and larger information flows correlate with less absolute poverty.

\section{THE LONG-RUN RELATIONSHIP BETWEEN GLOBALIZATION AND POVERTY}

As an alternative to the panel specification, we study the development of globalization and poverty by considering the difference over a longer time period, running the following regression:

$$
\Delta \text { Poverty }_{i}=\alpha+\beta_{1}\left(\Delta G l o b_{i}\right)+\beta_{2}\left(X_{i}\right)+\varepsilon_{i}
$$


In equation (2), $\Delta$ Poverty $i \quad$ refers to the difference in poverty in country $i$ over a certain time period. This specification maximizes the possibility of capturing mechanisms that decrease poverty in the long run by increasing growth. Following Ravallion (2006), we maximize the length of this time period for each country, and the dependent variable might consequently correspond to changes in poverty over different periods for different countries. To separate this analysis from the panel examination, we only include changes that take place over 10 to 15 years, excluding countries for which we only have information on poverty in two adjacent time periods. $\Delta G l o b$ refers to the change in globalization in country $\mathrm{i}$ and corresponds to the same number of years as the country-specific poverty spell. For example, in our sample there is information on poverty outcomes in Zambia for all four time periods of the panel. We therefore calculate the change in poverty by taking the poverty level in 2005 minus the poverty level in 1990. Likewise, we calculate the Zambian change in globalization using a 15-year time spell. To overcome potential reverse causality, we lag the change in globalization by one time period. In the Zambian example, this variable is thus derived by using data on globalization for 1985 and 1970.

A first difference analysis bundles all time-invariant country characteristics into an error component, and estimates the relationship between globalization and poverty robustly to latent heterogeneity due to time-invariant effects. Specifications, however, include information on economic growth and initial poverty, referring to the poverty level in the earliest year in each country's poverty spell. Table 7 presents baseline results, while table A5 in the Appendix shows a sensitivity analysis of long-run relationship estimations. In general, the long-run, first difference analysis confirms the previous results. While growth does decrease poverty, it is clearly not the most important mediator even in this longer time perspective, suggesting the largest part of the poverty-reducing effect of globalization is mediated through other factors. The result that trade restrictions and information flows matter are once again confirmed, while the positive poverty effect of cultural proximity appearing in some of the panel estimations is gone when applying a long-run perspective. 
TABLE 7. The long-run relationship between globalization and poverty - Baseline results

\begin{tabular}{|c|c|c|c|c|c|c|c|c|c|c|c|c|c|}
\hline & $(1)$ & (2) & (3) & (4) & (5) & (6) & $(7)$ & (8) & (9) & (10) & (11) & $(12)$ & (13) \\
\hline$\Delta \mathrm{KOF}$ & $\begin{array}{c}-0.731^{* * *} \\
{[0.189]}\end{array}$ & $\begin{array}{c}-0.549 * * * \\
{[0.203]}\end{array}$ & & & & & & & & & & & \\
\hline$\triangle \mathrm{KOF} 1$ & & & $\begin{array}{c}-0.278^{* *} \\
{[0.119]}\end{array}$ & $\begin{array}{l}-0.235^{*} \\
{[0.119]}\end{array}$ & & & & & & & & & \\
\hline$\triangle \mathrm{KOF} 2$ & & & & & $\begin{array}{c}-0.739 * * * \\
{[0.156]}\end{array}$ & $\begin{array}{c}-0.625 * * * \\
{[0.163]}\end{array}$ & & & & & & & \\
\hline$\Delta$ Flows & & & & & & & $\begin{array}{l}-0.091 \\
{[0.079]}\end{array}$ & & $\begin{array}{l}-0.081 \\
{[0.083]}\end{array}$ & & & & \\
\hline$\Delta$ Restrictions & & & & & & & & $\begin{array}{l}-0.212^{*} \\
{[0.106]}\end{array}$ & $\begin{array}{l}-0.208^{*} \\
{[0.106]}\end{array}$ & & & & \\
\hline$\Delta$ Personal contact & & & & & & & & & & $\begin{array}{l}-0.227 \\
{[0.242]}\end{array}$ & & & $\begin{array}{l}-0.071 \\
{[0.244]}\end{array}$ \\
\hline$\Delta$ Information flows & & & & & & & & & & & $\begin{array}{c}-0.419^{* * * *} \\
{[0.117]}\end{array}$ & & $\begin{array}{c}-0.385^{* * *} * \\
{[0.122]}\end{array}$ \\
\hline$\Delta$ Cultural proximity & & & & & & & & & & & & $\begin{array}{c}-0.113^{*} \\
{[0.0573]}\end{array}$ & $\begin{array}{l}-0.068 \\
{[0.058]}\end{array}$ \\
\hline Initial poverty & $\begin{array}{c}-0.292 * * * \\
{[0.054]}\end{array}$ & $\begin{array}{c}-0.299 * * * \\
{[0.053]}\end{array}$ & $\begin{array}{c}-0.233^{* * *} \\
{[0.055]}\end{array}$ & $\begin{array}{c}-0.263 * * * \\
{[0.052]}\end{array}$ & $\begin{array}{c}-0.335 * * * \\
{[0.057]}\end{array}$ & $\begin{array}{c}-0.336 * * * \\
{[0.054]}\end{array}$ & $\begin{array}{c}-0.238^{* * *} \\
{[0.062]}\end{array}$ & $\begin{array}{c}-0.229 * * * \\
{[0.062]}\end{array}$ & $\begin{array}{c}-0.235^{* * * *} \\
{[0.063]}\end{array}$ & $\begin{array}{c}-0.233^{* * *} \\
{[0.059]}\end{array}$ & $\begin{array}{c}-0.252 * * * \\
{[0.055]}\end{array}$ & $\begin{array}{c}-0.267 * * * \\
{[0.067]}\end{array}$ & $\begin{array}{c}-0.279 * * * \\
{[0.064]}\end{array}$ \\
\hline Economic growth & & $\begin{array}{c}-0.067^{* *} \\
{[0.028]}\end{array}$ & & $\begin{array}{c}-0.087 * * * \\
{[0.025]}\end{array}$ & & $\begin{array}{c}-0.054^{* *} \\
{[0.025]}\end{array}$ & $\begin{array}{c}-0.069 * * * * \\
{[0.021]}\end{array}$ & $\begin{array}{c}-0.071 * * * \\
{[0.018]}\end{array}$ & $\begin{array}{c}-0.069 * * * \\
{[0.019]}\end{array}$ & $\begin{array}{c}-0.077 * * * \\
{[0.021]}\end{array}$ & $\begin{array}{c}-0.056^{* *} \\
{[0.024]}\end{array}$ & $\begin{array}{c}-0.079 * * * \\
{[0.025]}\end{array}$ & $\begin{array}{c}-0.055^{* * *} \\
{[0.027]}\end{array}$ \\
\hline Constant & $\begin{array}{c}13.51 * * * \\
{[3.605]}\end{array}$ & $\begin{array}{c}13.55^{* * * *} \\
{[3.605]}\end{array}$ & $\begin{array}{l}5.331 * * \\
{[2.270]}\end{array}$ & $\begin{array}{c}8.782 * * * \\
{[2.369]} \\
\end{array}$ & $\begin{array}{c}14.19^{* * *} \\
{[3.320]} \\
\end{array}$ & $\begin{array}{c}14.65 * * * \\
{[3.065]}\end{array}$ & $\begin{array}{l}4.974 * * \\
{[1.925]}\end{array}$ & $\begin{array}{c}7.362 * * * \\
{[2.537]} \\
\end{array}$ & $\begin{array}{c}8.404 * * * \\
{[2.521]} \\
\end{array}$ & $\begin{array}{l}4.235 * * \\
{[1.730]}\end{array}$ & $\begin{array}{c}13.17 * * * \\
{[3.395]}\end{array}$ & $\begin{array}{c}7.236 * * * \\
{[2.693]} \\
\end{array}$ & $\begin{array}{c}14.59 * * * \\
{[3.856]}\end{array}$ \\
\hline Observations & 70 & 70 & 70 & 70 & 71 & 71 & 59 & 59 & 59 & 59 & 59 & 59 & 59 \\
\hline R-squared & 0.356 & 0.405 & 0.280 & 0.374 & 0.465 & 0.496 & 0.309 & 0.343 & 0.349 & 0.296 & 0.434 & 0.323 & 0.446 \\
\hline
\end{tabular}

Robust standard errors in brackets.

$*, * *$, and ${ }^{* * *}$ denote statistical significance at the $10 \%, 5 \%$, and $1 \%$ levels, respectively. 


\section{CONCLUDING DISCUSSION}

We set out to test the links and mechanisms from globalization to poverty reduction. Our results are coherent enough to identify some interesting patterns. First, there is no evidence that globalization is associated with higher poverty levels in developing countries. While we cannot identify causal effects, the relationship between the lagged aggregate KOF Index of globalization and poverty is always negative and significant in almost all regressions. To describe the size of the effect, consider the case of Bangladesh. Between 1980 and 2000, the country increased its KOF value from 8 to 30. According to our estimates, this translates to a reduction of absolute poverty by 12 percentage points. The size of the effect is not at all remarkable, as it roughly means that it takes a two standard deviation increase in globalization to decrease poverty by half a standard deviation. Note, however, that the effect is in addition to the decrease explained by GDP growth.

Looking closer at the factors included in the index, less trade restrictions and larger information flows are robustly associated with lower poverty levels. Our results also indicate that globalization decreases poverty more when the informal and the rural sectors are relatively bigger. Finally, we find clear evidence that the main part of the poverty-decreasing effect is not mediated via the growth channel.

Analyzing trade flows only, the standard approach (assuming that trade increases growth and growth decreases poverty) holds up well. In both the short-run and long-run analysis, we find that higher trade flows are on average followed by lower poverty, but the effect is no longer significant once we control for income or growth. However, the fact that trade restrictions turn out to be more robust than trade flows should probably be carefully interpreted: Deaton (1995) notes that trade data may be biased upwards due to over-invoicing of imports, a method often used to transfer funds abroad from lowincome countries, causing a systematic bias in trade data and in national accounts.

For both trade restrictions and information flows, a relatively large poverty-decreasing effect remains after controlling for GDP per capita, suggesting that the standard approach actually underestimates the poverty-reducing impact of globalization. How can the result that globalization decreases poverty but not via growth be explained?

A possible explanation is that there are income distribution effects such that the incomes of the poor increase more than the average income. Another possibility is that the result is caused by measurement errors in the GDP data. As discussed by Heston (1994), productivity increases in the subsistence sector and the informal sector, which are often insufficiently captured in GDP data. Because these sectors are typically bigger when the rural sector is larger, this explanation is supported by the interaction effects, which suggest that globalization reduces poverty more when the informal and rural 
sectors are larger. These results should therefore be carefully interpreted and may simply indicate that less actual growth is captured by GDP data in countries with bigger rural and informal sectors. ${ }^{18}$

Despite these concerns about data quality and measurement problems, we still believe our results leave room for cautious optimism. The rapid increase in usage of mobile phones and the Internet is most likely not a statistical artifact caused by measurement problems. As noted by Aker and Mbiti (2010), there has been a massive increase in mobile phone use subscribers in sub-Saharan Africa during the past decade, and according to our estimates this should make it easier for these countries to meet the first UN Millennium Development Goals of cutting the proportion of people living on less than one dollar a day by 2015 in half. Moreover, although the fact that many low-income countries embarked on programs of external economic liberalization in recent decades has been intensely debated, our analysis suggests that the underlying premises of current and previous poverty reduction strategies are correct: poverty reduction can be achieved by means of closer economic integration and higher levels of globalization.

${ }_{18}$ Deaton (1995) also discusses complications with the GDP data in developing countries, and suggests that consumption measures based on household surveys may be preferable to measures based on national accounts. 


\section{APPENDIX}

TABLE A1. The KOF Index of Globalization

\section{A. Economic Globalization}

i) Actual Flows

Trade (percent of GDP)

Foreign direct investment, flows (percent of GDP)

Foreign direct investment, stocks (percent of GDP)

Portfolio investment (percent of GDP)

ii) Restrictions

Income payments to foreign nationals (percent of GDP)

Hidden import barriers

Mean tariff rate

Taxes on international trade (percent of current revenue)

Capital account restrictions

B. Social Globalization

i) Data on Personal Contacts

Outgoing telephone traffic

Transfers (percent of GDP)

International tourism

Foreign population (percent of total population)

International letters (per capita)

ii) Data on Information Flows

Internet hosts (per 1000 people)

Internet users (per 1000 people)

Cable television (per 1000 people)

Trade in newspapers (percent of GDP)

Radios (per 1000 people)

iii) Data on Cultural Proximity

Number of McDonald's restaurants (per capita)

Number of IKEAs (per capita)

Trade in books (percent of GDP)

\section{Political Globalization}

Embassies in country

Membership in international organizations

Participation in UN Security Council missions 
TABLE A2. Descriptive statistics

\begin{tabular}{|c|c|c|c|c|c|}
\hline Variable & Mean & Std. Dev. & Min & Max & Source \\
\hline Headcount & 24,80 & 25,29 & 0,00 & 92,55 & World Bank 2010a \\
\hline Poverty gap & 9,82 & 12,44 & 0,00 & 63,34 & World Bank 2010a \\
\hline Squared poverty gap & 5,35 & 7,99 & 0,00 & 48,51 & World Bank 2010a \\
\hline $\mathrm{KOF}$ & 45,41 & 12,19 & 17,11 & 80,46 & Dreher et al. 2008 \\
\hline KOF1 & 45,96 & 14,62 & 10,66 & 88,17 & Dreher et al. 2008 \\
\hline $\mathrm{KOF} 2$ & 38,83 & 15,94 & 9,09 & 82,75 & Dreher et al. 2008 \\
\hline Flows & 51,95 & 17,61 & 8,76 & 92,21 & Dreher et al. 2008 \\
\hline Restrictions & 45,27 & 17,05 & 10,16 & 93,59 & Dreher et al. 2008 \\
\hline Personal contact & 37,13 & 16,40 & 8,74 & 79,23 & Dreher et al. 2008 \\
\hline Information flows & 42,33 & 18,98 & 6,29 & 88,34 & Dreher et al. 2008 \\
\hline Cultural proximity & 35,46 & 22,26 & 1,00 & 85,98 & Dreher et al. 2008 \\
\hline Ln Real GDP per capita (PPP) & 8,01 & 0,95 & 5,58 & 10,07 & World Bank 2010b \\
\hline Economic growth & 10,81 & 20,07 & $-64,87$ & 96,97 & World Bank 2010b \\
\hline Government expenditure (percent of GDP) & 13,74 & 5,07 & 3,65 & 32,79 & World Bank 2010b \\
\hline Urban population (share of total) & 47,98 & 20,21 & 6,28 & 92,19 & World Bank 2010b \\
\hline Inflation & 2,37 & 1,33 & $-0,12$ & 7,79 & World Bank 2010b \\
\hline Primary education & 5,46 & 1,01 & 3,00 & 8,00 & World Bank 2010b \\
\hline Polity2 & 2,80 & 6,22 & $-9,00$ & 10,00 & Marshall and Jaggers 2009 \\
\hline East Asia \& Pacific & 0,12 & 0,32 & 0,00 & 1,00 & World Bank 2010b \\
\hline Europe and Central Asia & 0,24 & 0,43 & 0,00 & 1,00 & World Bank 2010b \\
\hline Latin America and the Carribean & 0,25 & 0,43 & 0,00 & 1,00 & World Bank 2010b \\
\hline Middle East and North Africa & 0,07 & 0,26 & 0,00 & 1,00 & World Bank 2010b \\
\hline South Asia & 0,06 & 0,23 & 0,00 & 1,00 & World Bank 2010b \\
\hline sub-Saharan Africa & 0,26 & 0,44 & 0,00 & 1,00 & World Bank 2010b \\
\hline
\end{tabular}

TABLE A3. Sample coverage

\begin{tabular}{|c|c|c|c|c|}
\hline Albania & Colombia & Indonesia & Nicaragua & Togo \\
\hline Algeria & Congo, Dem. Rep. & Iran, Islamic Rep. & Niger & Trinidad and Tobago \\
\hline Angola & Congo, Rep. & Jamaica & Nigeria & Tunisia \\
\hline Argentina & Costa Rica & Jordan & Pakistan & Turkey \\
\hline Armenia & Cote d'Ivoire & Kazakhstan & Panama & Uganda \\
\hline Azerbaijan & Croatia & Kenya & Papua New Guinea & Ukraine \\
\hline Bangladesh & Dominican Republic & Kyrgyz Republic & Paraguay & Uruguay \\
\hline Belarus & Ecuador & Latvia & Peru & Venezuela, RB \\
\hline Benin & Egypt, Arab Rep. & Lesotho & Philippines & Vietnam \\
\hline Bolivia & El Salvador & Lithuania & Poland & Yemen, Rep. \\
\hline Bosnia and Herzegovina & Estonia & Macedonia, FYR & Romania & Zambia \\
\hline Botswana & Ethiopia & Madagascar & Russian Federation & \\
\hline Brazil & Gabon & Malawi & Rwanda & \\
\hline Bulgaria & Gambia, The & Malaysia & Senegal & \\
\hline Burkina Faso & Georgia & Mali & Sierra Leone & \\
\hline Burundi & Ghana & Mauritania & Slovenia & \\
\hline Cambodia & Guatemala & Mexico & South Africa & \\
\hline Cameroon & Guinea-Bissau & Moldova & Sri Lanka & \\
\hline Cape Verde & Guyana & Mongolia & Suriname & \\
\hline Central African Republic & Haiti & Morocco & Swaziland & \\
\hline Chad & Honduras & Mozambique & Tajikistan & \\
\hline Chile & Hungary & Namibia & Tanzania & \\
\hline China & India & Nepal & Thailand & \\
\hline
\end{tabular}


TABLE A4. Sensitivity tests

\begin{tabular}{|c|c|c|c|c|c|c|c|c|c|}
\hline \multirow{2}{*}{$\begin{array}{l}\text { Variation } \\
\text { Bascline model }\end{array}$} & \multicolumn{2}{|c|}{ Composite KOF index } & \multicolumn{6}{|c|}{ Significant components } & \multirow{2}{*}{$\begin{array}{l}\text { Comments } \\
\text { Baseline estimates: Corresponds to } \\
\text { the results in Table } 1 \text { and Table } 2 \\
\text { when GDP is controlled for. }\end{array}$} \\
\hline & $\begin{array}{l}-1.23^{* * *} \\
0.01^{* * *}\end{array}$ & $\begin{array}{l}{[0.40]} \\
{[0.00]}\end{array}$ & $\begin{array}{l}\text { KOF1 (t-1) } \\
\text { KOF2 }(t-1) \\
\text { KOF3 }(t-1)\end{array}$ & $\begin{array}{c}-0.83^{* * *} \\
0.01^{* * *} \\
-0.81^{* * *} \\
0.01^{* * *} \\
0.48^{* *} \\
-0.00^{* *}\end{array}$ & $\begin{array}{l}{[0.25]} \\
{[0.00]} \\
{[0.27]} \\
{[0.00]} \\
{[0.19]} \\
{[0.00]}\end{array}$ & $\begin{array}{l}\text { Restrictions (t-1) } \\
\text { Information flows (t-1) } \\
\text { Cultural proximity (t-1) }\end{array}$ & $\begin{array}{c}-0.61^{* *} \\
0.01^{* *} \\
-1.00^{* * *} \\
0.01^{* * *} \\
0.18^{* *} \\
-0.00^{* *}\end{array}$ & $\begin{array}{l}{[0.27]} \\
{[0.00]} \\
{[0.19]} \\
{[0.00]} \\
{[0.09]} \\
{[0.00]}\end{array}$ & \\
\hline Random effects (RE) model & $\begin{array}{l}-1.22^{* * * *} \\
0.01^{* * *}\end{array}$ & $\begin{array}{l}{[0.37]} \\
{[0.00]}\end{array}$ & $\begin{array}{l}\text { KOF1 (t-1) } \\
\text { KOF2 }(t-1) \\
\text { KOF3 }(t-1)\end{array}$ & $\begin{array}{c}-0.97^{* * *} \\
0.01^{* * * *} \\
-0.92^{* * *} \\
0.01^{* * *} \\
0.47^{* * *} \\
-0.00^{* * *}\end{array}$ & $\begin{array}{l}{[0.21]} \\
{[0.00]} \\
{[0.23]} \\
{[0.00]} \\
{[0.17]} \\
{[0.00]}\end{array}$ & $\begin{array}{l}\text { Trade flows (t-1) } \\
\text { Restrictions (t-1) } \\
\text { Personal contac (t-1) } \\
\text { Information flows (t-1) } \\
\text { Cultural proximity (t-1) }\end{array}$ & $\begin{array}{c}-0.25^{*} \\
0.00^{*} \\
-0.68^{* * *} \\
0.01^{* * *} \\
-0.67^{*} \\
0.01^{* *} \\
-1.12^{* * *} \\
0.01^{* * *} \\
0.28^{* * *} \\
-0.00^{* * *}\end{array}$ & $\begin{array}{l}{[0.15]} \\
{[0.00]} \\
{[0.19]} \\
{[0.00]} \\
{[0.38]} \\
{[0.00]} \\
{[0.18]} \\
{[0.00]} \\
{[0.09]} \\
{[0.00]}\end{array}$ & \\
\hline $\begin{array}{l}\text { Controling for } \\
\text { non-lagged globalization }\end{array}$ & $\begin{array}{l}-0.92^{* * *} \\
0.01^{* * *}\end{array}$ & $\begin{array}{l}{[0.33]} \\
{[0.00]}\end{array}$ & $\begin{array}{l}\text { KOFl (t) } \\
\text { KOF2 (t) } \\
\text { KOF3 (t) }\end{array}$ & $\begin{array}{r}-0.74^{* * *} \\
0.01^{* * *} \\
-1.04^{* * *} \\
0.01^{* * *} \\
0.57^{* * *} \\
-0.00^{* *}\end{array}$ & $\begin{array}{l}{[0.25]} \\
{[0.00]} \\
{[0.26]} \\
{[0.00]} \\
{[0.21]} \\
{[0.00]}\end{array}$ & Information flows & $\begin{array}{l}-0.91^{* * *} \\
0.01^{* * *}\end{array}$ & $\begin{array}{l}{[0.19]} \\
{[0.00]}\end{array}$ & \\
\hline $\begin{array}{l}\text { Exduding extreme } \\
\text { values of globalization }\end{array}$ & $\begin{array}{l}-1.49^{* * *} \\
0.02^{* * *}\end{array}$ & $\begin{array}{l}{[0.43]} \\
{[0.00]}\end{array}$ & $\begin{array}{l}\text { KOF1 (t-1) } \\
\text { KOF2 }(t-1)\end{array}$ & $\begin{array}{c}-0.97^{* * *} \\
0.01^{* * *} \\
-0.84^{* * *} \\
0.01^{* * *}\end{array}$ & $\begin{array}{l}{[0.28]} \\
{[0.00]} \\
{[0.30]} \\
{[0.00]}\end{array}$ & $\begin{array}{l}\text { Restrictions (t-1) } \\
\text { Information flows (t-1) } \\
\text { Cultural proximity (t-1) }\end{array}$ & $\begin{array}{c}-0.63^{* *} \\
0.01^{* *} \\
-1.03^{* * *} \\
0.01^{* * *} \\
0.24^{* *} \\
-0.00^{* *}\end{array}$ & $\begin{array}{l}{[0.29]} \\
{[0.00]} \\
{[0.22]} \\
{[0.00]} \\
{[0.11]} \\
{[0.00]}\end{array}$ & $\begin{array}{l}\text { Exduding index obscrvations } \\
\text { further than } 2 \text { standard deviations } \\
\text { away from the sample mean }\end{array}$ \\
\hline
\end{tabular}

Robust standard errors in brackets

${ }^{*}, * *$, and $*$ denote statistical significance at the $10 \%, 5 \%$, and $1 \%$ levels, respectively. 
Table A4. Sensitivity tests, cont.

\begin{tabular}{|c|c|c|c|c|c|c|c|c|c|}
\hline Variation & Compostel & & Sgificant $\infty$ & vents & & & & & Comments \\
\hline $\begin{array}{l}\text { Exduding extreme } \\
\text { values of poverty }\end{array}$ & $\begin{array}{l}-1.11^{* * *} \\
0.01^{* *}\end{array}$ & $\begin{array}{l}{[0.40]} \\
{[0.00]}\end{array}$ & $\begin{array}{l}\text { KOF1 (t-1) } \\
\text { KOF2 (t-1) }\end{array}$ & $\begin{array}{l}-0.82^{* *} \\
0.01^{* *} \\
-0.84^{* * *} \\
0.01^{* *}\end{array}$ & $\begin{array}{l}{[0.25]} \\
{[0.00]} \\
{[0.27]} \\
{[0.00]}\end{array}$ & $\begin{array}{l}\text { Restrictions (t-1) } \\
\text { Intormation flows (t-1) }\end{array}$ & $\begin{array}{l}-0.64^{* *} \\
0.01^{* *} \\
-0.90^{* * *} \\
0.01^{* *}\end{array}$ & $\begin{array}{l}{[0.27]} \\
{[0.00]} \\
{[0.19]} \\
{[0.00]}\end{array}$ & $\begin{array}{l}\text { Exduding heedoount obervations } \\
\text { further than } 2 \text { standad devizions } \\
\text { avay from the sample mean }\end{array}$ \\
\hline $\begin{array}{l}\text { Alternative measure of poverty - } \\
\text { Poverty gap }\end{array}$ & $\begin{array}{l}-0.0 \sigma^{* * *} \\
0.01^{* * *}\end{array}$ & $\begin{array}{l}{[0.24]} \\
{[0.00]}\end{array}$ & KOF1 (t-1) & $\begin{array}{l}-0.49^{* * *} \\
0.01^{* *}\end{array}$ & $\begin{array}{l}{[0.16]} \\
{[0.00]}\end{array}$ & $\begin{array}{l}\text { Restrictions (t-1) } \\
\text { Intormation flows (t-1) } \\
\text { Cultura proximity (t-1) }\end{array}$ & $\begin{array}{c}-0.37^{* *} \\
0.00^{* *} \\
-0.45^{* * *} \\
0.00^{* * *} \\
0.14^{* *} \\
-0.00^{* *}\end{array}$ & $\begin{array}{l}{[0.17]} \\
{[0.00]} \\
{[0.11]} \\
{[0.00]} \\
{[0.06]} \\
{[0.00]}\end{array}$ & $\begin{array}{l}\text { Using the squared poverty gap } \\
\text { æs the dependent variable generaes simila results }\end{array}$ \\
\hline $\begin{array}{l}\text { Exduding } \\
\text { sub-Seharan African countries } \\
\text { (36 countries) }\end{array}$ & $\begin{array}{l}-1.18^{* *} \\
0.01^{* *}\end{array}$ & $\begin{array}{l}{[0.43]} \\
{[0.00]}\end{array}$ & $\begin{array}{l}\text { KOF1 (t-1) } \\
\text { KOF2 (t-1) }\end{array}$ & $\begin{array}{c}-0.67^{* *} \\
0.01^{* *} \\
-0.93^{* * *} \\
0.01^{* * *}\end{array}$ & $\begin{array}{l}{[0.28]} \\
{[0.00]} \\
{[0.29]} \\
{[0.00]}\end{array}$ & $\begin{array}{l}\text { Retrictions (t-1) } \\
\text { Information flows (t-1) } \\
\text { Cultura proximity (t-1) }\end{array}$ & $\begin{array}{c}-0.81^{* * *} \\
0.01^{* *} \\
-0.98^{* * *} \\
0.01^{* * *} \\
0.15^{*} \\
-0.00^{* *}\end{array}$ & $\begin{array}{l}{[0.29]} \\
{[0.00]} \\
{[0.21]} \\
{[0.00]} \\
{[0.09]} \\
{[0.00]}\end{array}$ & \\
\hline $\begin{array}{l}\text { Exduding } \\
\text { Latin American countries } \\
\text { (23 countries) }\end{array}$ & $\begin{array}{l}-1.33^{* *} \\
0.01^{* * *}\end{array}$ & $\begin{array}{l}{[0.49]} \\
{[0.00]}\end{array}$ & $\begin{array}{l}\text { KOF1 (t-1) } \\
\text { KOF2 (t-1) }\end{array}$ & $\begin{array}{l}-0.85^{* * *} \\
0.01^{* * *} \\
-0.96^{* * *} \\
0.01^{* * *}\end{array}$ & $\begin{array}{l}{[0.28]} \\
{[0.00]} \\
{[0.29]} \\
{[0.00]}\end{array}$ & Information flows (t-1) & $\begin{array}{l}-0.9 Q^{* *} \\
0.01^{* * *}\end{array}$ & $\begin{array}{l}{[0.22]} \\
{[0.00]}\end{array}$ & \\
\hline $\begin{array}{l}\text { Exduding East Asian countries } \\
\text { (11 countries) }\end{array}$ & $\begin{array}{l}-0.85^{*} \\
0.01^{* * *}\end{array}$ & $\begin{array}{l}{[0.43]} \\
{[0.00]}\end{array}$ & $\begin{array}{l}\text { KOF1 (t-1) } \\
\text { KOF2 (t-1) }\end{array}$ & $\begin{array}{l}-0.76^{* *} \\
0.01^{* * *} \\
-0.36^{*} \\
0.01^{* * *}\end{array}$ & $\begin{array}{l}{[0.27]} \\
{[0.00]} \\
{[0.21]} \\
{[0.00]}\end{array}$ & $\begin{array}{l}\text { Restrictions (t-1) } \\
\text { Information flows (t-1) } \\
\text { Cultura proximity (t-1) }\end{array}$ & $\begin{array}{c}-0.50^{*} \\
0.00^{* *} \\
-0.85^{* * *} \\
0.01^{* * *} \\
0.24^{* * *} \\
-0.00^{* * *}\end{array}$ & $\begin{array}{l}{[0.26]} \\
{[0.00]} \\
{[0.20]} \\
{[0.00]} \\
{[0.09]} \\
{[0.00]}\end{array}$ & \\
\hline
\end{tabular}

Pobug standard erors in brackets

$\because \cdots$, and ${ }^{\cdots}$ denotestatistical significances the $10 \%, 5 \%$, and $1 \%$ levels respectively. 
TABLE A5. The long-run relationship between globalization and poverty - Sensitivity analysis ${ }^{19}$

\begin{tabular}{|c|c|c|c|c|c|c|c|c|c|c|c|c|c|c|c|c|c|c|}
\hline & (1) & (2) & (3) & (4) & (5) & (6) & (7) & (8) & (9) & (10) & (11) & (12) & (13) & (14) & (15) & (16) & (17) & (18) \\
\hline$\triangle \mathrm{KOF}$ & $\begin{array}{l}-0.329^{*} \\
{[0.170]}\end{array}$ & $\begin{array}{c}-0.623^{* \star} \\
{[0.243]}\end{array}$ & $\begin{array}{l}-0.332^{\star} \\
{[0.194]}\end{array}$ & $\begin{array}{l}-0.303 \\
{[0.211]}\end{array}$ & & & & & & & & & & & & & & \\
\hline$\triangle \mathrm{KOF} 1$ & & & & & $\begin{array}{c}-0.177^{* *} \\
{[0.042]}\end{array}$ & $\begin{array}{c}-0.266^{* \star \star} \\
{[0.053]}\end{array}$ & $\begin{array}{l}-0.151 \\
{[0.119]}\end{array}$ & $\begin{array}{r}-0.106 \\
{[0.124]}\end{array}$ & & & & & & & & & & \\
\hline$\triangle \mathrm{KOF} 2$ & & & & & & & & & $\begin{array}{c}-0.391^{\star \star \star} \\
{[0.134]}\end{array}$ & $\begin{array}{c}-0.504^{* * *} \\
{[0.155]}\end{array}$ & $\begin{array}{c}-0.470^{\star \star \star} \\
{[0.163]}\end{array}$ & & & & & & & \\
\hline$\Delta$ Flows & & & & & & & & & & & & $\begin{array}{c}-0.060 \\
{[0.081]}\end{array}$ & $\begin{array}{c}-0.059 \\
{[0.135]}\end{array}$ & $\begin{array}{c}-0.034 \\
{[0.092]}\end{array}$ & $\begin{array}{c}-0.007 \\
{[0.089]}\end{array}$ & & & \\
\hline$\Delta$ Restrictions & & & & & & & & & & & & $\begin{array}{c}-0.144 \\
{[0.103]}\end{array}$ & $\begin{array}{c}-0.129 \\
{[0.234]}\end{array}$ & $\begin{array}{l}-0.120 \\
{[0.100]}\end{array}$ & $\begin{array}{c}-0.113 \\
{[0.104]}\end{array}$ & & & \\
\hline$\Delta$ Personal contact & & & & & & & & & & & & & & & & $\begin{array}{l}-0.004 \\
{[0.258]}\end{array}$ & $\begin{array}{l}-0.059 \\
{[0.263]}\end{array}$ & $\begin{array}{l}-0.049 \\
{[0.277]}\end{array}$ \\
\hline$\Delta$ Information flows & & & & & & & & & & & & & & & & $\begin{array}{l}-0.301^{\star *} \\
{[0.115]}\end{array}$ & $\begin{array}{l}-0.320^{* *} \\
{[0.122]}\end{array}$ & $\begin{array}{l}-0.311^{\star * *} \\
{[0.138]}\end{array}$ \\
\hline$\Delta$ Cultura proximity & & & & & & & & & & & & & & & & $\begin{array}{l}-0.021 \\
{[0.052]}\end{array}$ & $\begin{array}{l}-0.040 \\
{[0.052]}\end{array}$ & $\begin{array}{l}-0.024 \\
{[0.052]}\end{array}$ \\
\hline Initial poverty & $\begin{array}{c}-0.199^{* * *} \\
{[0.043]}\end{array}$ & $\begin{array}{c}-0.309^{* \star \star} \\
{[0.056]}\end{array}$ & $\begin{array}{c}-0.400^{* \star *} \\
{[0.072]}\end{array}$ & $\begin{array}{c}-0.447^{\star * *} \\
{[0.086]}\end{array}$ & $\begin{array}{c}-0.063^{\star \star \star} \\
{[0.016]}\end{array}$ & $\begin{array}{c}-0.087^{\star \star *} \\
{[0.026]}\end{array}$ & $\begin{array}{c}-0.391^{* * *} \\
{[0.074]}\end{array}$ & $\begin{array}{c}-0.441^{* \star \star} \\
{[0.085]}\end{array}$ & $\begin{array}{c}-0.236^{\star \star \star} \\
{[0.046]}\end{array}$ & $\begin{array}{c}-0.411^{\star * *} \\
{[0.066]}\end{array}$ & $\begin{array}{c}-0.449 * \star \star \\
{[0.083]}\end{array}$ & $\begin{array}{c}-0.154^{* \star \star} \\
{[0.054]}\end{array}$ & $\begin{array}{c}-0.212^{* * *} \\
{[0.070]}\end{array}$ & $\begin{array}{c}-0.396^{\star \star \star} \\
{[0.089]}\end{array}$ & $\begin{array}{c}-0.436^{\star \star \star} \\
{[0.098]}\end{array}$ & $\begin{array}{c}-0.184^{* * *} \\
{[0.057]}\end{array}$ & $\begin{array}{l}-0.359^{\star \star \star *} \\
{[0.078]}\end{array}$ & $\begin{array}{c}-0.403^{* \star \star} \\
{[0.099]}\end{array}$ \\
\hline Economic growth & $\begin{array}{c}-0.052^{* * *} \\
{[0.018]}\end{array}$ & $\begin{array}{c}-0.090^{* *} \\
{[0.036]}\end{array}$ & $\begin{array}{l}-0.051^{\star *} \\
{[0.022]}\end{array}$ & $\begin{array}{l}-0.054^{\star *} \\
{[0.024]}\end{array}$ & $\begin{array}{l}-0.215^{\star *} \\
{[0.103]}\end{array}$ & $\begin{array}{l}-0.279^{* *} \\
{[0.134]}\end{array}$ & $\begin{array}{c}-0.060^{* * *} \\
{[0.020]}\end{array}$ & $\begin{array}{l}-0.061^{* \star \star} \\
{[0.023]}\end{array}$ & $\begin{array}{l}-0.050^{* *} \\
{[0.019]}\end{array}$ & $\begin{array}{l}-0.044^{*} \\
{[0.022]}\end{array}$ & $\begin{array}{l}-0.047^{\star} \\
{[0.025]}\end{array}$ & $\begin{array}{l}-0.057^{* * *} \\
{[0.016]}\end{array}$ & $\begin{array}{l}-0.068^{* * *} \\
{[0.022]}\end{array}$ & $\begin{array}{l}-0.046^{* *} \\
{[0.019]}\end{array}$ & $\begin{array}{l}-0.039^{\star} \\
{[0.023]}\end{array}$ & $\begin{array}{l}-0.049^{\star *} \\
{[0.0189]}\end{array}$ & $\begin{array}{l}-0.044^{\star} \\
{[0.022]}\end{array}$ & $\begin{array}{l}-0.048^{\star} \\
{[0.026]}\end{array}$ \\
\hline Sub-Saharan Africa & & & $\begin{array}{l}10.96^{* *} \\
{[5.042]}\end{array}$ & $\begin{array}{l}13.04^{* *} \\
{[6.285]}\end{array}$ & & & $\begin{array}{l}1219^{* *} \\
{[4.988]}\end{array}$ & $\begin{array}{l}14.78^{\star *} \\
{[5.802]}\end{array}$ & & $\begin{array}{l}8.227^{*} \\
{[4.491]}\end{array}$ & $\begin{array}{l}10.29^{*} \\
{[5.642]}\end{array}$ & & & $\begin{array}{l}14.27^{\star \star} \\
{[6.016]}\end{array}$ & $\begin{array}{l}17.04^{* *} \\
{[6.500]}\end{array}$ & & $\begin{array}{c}9.085 \\
{[5.538]}\end{array}$ & $\begin{array}{c}11.58 \\
{[7.079]}\end{array}$ \\
\hline South Asia & & & & $\begin{array}{c}6.508 \\
{[6.080]}\end{array}$ & & & & $\begin{array}{r}6.946 \\
{[5.771]}\end{array}$ & & & $\begin{array}{c}5.366 \\
{[6.084]}\end{array}$ & & & & $\begin{array}{c}6.178 \\
{[6.094]}\end{array}$ & & & $\begin{array}{r}5.230 \\
{[6.777]}\end{array}$ \\
\hline Latin America & & & & $\begin{array}{r}-1.683 \\
{[2.218]}\end{array}$ & & & & $\begin{array}{r}-0.960 \\
{[2.134]}\end{array}$ & & & $\begin{array}{l}-1.060 \\
{[1.999]}\end{array}$ & & & & $\begin{array}{c}0.512 \\
{[1.990]}\end{array}$ & & & $\begin{array}{l}-1.121 \\
{[2.266]}\end{array}$ \\
\hline Eas Asia & & & & $\begin{array}{r}-0.358 \\
{[3.464]}\end{array}$ & & & & $\begin{array}{r}-0.324 \\
{[3.592]}\end{array}$ & & & $\begin{array}{l}-0.0121 \\
{[3.527]}\end{array}$ & & & & $\begin{array}{l}-2839 \\
{[2.899]}\end{array}$ & & & $\begin{array}{l}-0.315 \\
{[3.308]}\end{array}$ \\
\hline Constant & $\begin{array}{c}8.157^{* * *} \\
{[2.830]} \\
\end{array}$ & $\begin{array}{c}15.49^{* * *} \\
{[4.551]}\end{array}$ & $\begin{array}{c}9.618^{* * *} \\
{[3.450]}\end{array}$ & $\begin{array}{l}10.08^{* *} \\
{[4.125]}\end{array}$ & $\begin{array}{c}6.455^{* \star \star *} \\
{[1.919]}\end{array}$ & $\begin{array}{c}9.579^{* * *} \\
{[2.569]}\end{array}$ & $\begin{array}{c}6.797^{* * *} \\
{[2.481]}\end{array}$ & $\begin{array}{l}6.628^{\star *} \\
{[2.700]}\end{array}$ & $\begin{array}{c}9.630^{* * *} \\
{[2457]}\end{array}$ & $\begin{array}{c}12.51^{* *} \\
{[2.965]}\end{array}$ & $\begin{array}{l}12.58^{* * *} \\
{[3.229]}\end{array}$ & $\begin{array}{l}5.557^{* *} \\
{[2.139]}\end{array}$ & $\begin{array}{c}6.175 \\
{[4.200]}\end{array}$ & $\begin{array}{l}5.975^{\star *} \\
{[2.652]}\end{array}$ & $\begin{array}{l}5.210^{\circ} \\
{[2.894]}\end{array}$ & $\begin{array}{c}9.858^{* * *} \\
{[3.109]}\end{array}$ & $\begin{array}{c}12.01^{* * *} \\
{[3.763]}\end{array}$ & $\begin{array}{l}12.05^{* *} \\
{[4.531]}\end{array}$ \\
\hline Observations & 65 & 67 & 70 & 70 & 65 & 68 & 70 & 70 & 66 & 71 & 71 & 55 & 45 & 59 & 59 & 55 & 59 & 59 \\
\hline R-squared & 0.278 & 0.399 & 0.469 & 0.490 & 0.280 & 0.376 & 0.461 & 0.480 & 0.344 & 70.532 & 0.544 & 0.242 & 0.262 & 0.455 & 0.476 & 0.316 & 0.491 & 0.505 \\
\hline
\end{tabular}

Robust standerd er rors in brakets

$\because \cdots$, and ${ }^{\cdots \cdots}$ denote staistical significanoe at the $10 \%, 5 \%$, and $1 \%$ leveds respectively.

${ }^{19}$ Explanatory note: For each dimension of globalization and related sub-components, we run four regressions to test the robustness of our baseline findings on the long-run relationship between globalization and poverty. First, we exclude observations with extreme values of changes in poverty defined as countries with at least a change in poverty over the period further than two standard deviations away from the sample mean. Second, we exclude extreme values of changes in globalization according to the same rule. Finally, we sequentially control for geographical regions. With regard to social globalization, there are no observations classified as extreme values resulting in three rather than four sensitivity regressions. 


\section{REFERENCES}

Agénor, Pierre-Richard. 2004. Does globalization hurt the poor? International Economics and Economic Policy 1(1):21-51.

Aisbett, E., Harrison, A., and Zwane, A. P. 2005. Globalization and Poverty: What is the evidence? Paper prepared for the conference in honor of J Bahagwati "Globalization: Prospects and Problems".

Aker, Jenny C, and Mbiti, Isaac M. 2010. Mobile Phones and Economic Development in Africa. Journal of Economic Perspectives 24(3):207-32.

Anand, Sudhir, Segal, Paul , and Stiglitz, Joseph. 2010. Debates on the measurement of global poverty. In S. Anand, P. Segal, and J. Stiglitz (Eds.), Debates in the Measurement of Global Poverty: Oxford University Press.

Arribas, Ivain, Perez, Francisco, and Tortosa-Ausina, Emili. 2009. Measuring Globalization of International Trade: Theory and Evidence. World Development 37(1):127-127.

Bergh, Andreas, and Nilsson, Therese. 2010. Do liberalization and globalization increase income inequality? Forthcoming in European Journal of Political Economy.

Bhagwati, Jagdish, and Srinivasan, T. N. 2002. Trade and Poverty in the Poor Countries. American Economic Review 92(2):180-183.

Bourguignon, François J. 2004. The Poverty-growth-inequality triangle. Indian Council for Research on International Economic Relations, New Delhi Working Papers 125.

Chao, C. C., Hazari, B. R., and Sgro, P. M. 2004. Tourism, globalization, social externalities, and domestic welfare. Research in International Business and Finance 18(2):141-149.

Deaton, Angus. 1995. Data and Econometric Tools for Development Analysis. In J. Behrman, and T.N. Srinivasan (Eds.), Handbook of Development Economics. Vol. 3a. 1785-1882. Amsterdam and New York, 1995, v. 3A: Elsevier, North-Holland.

Deaton, Angus. 2001. Counting the world's poor: Problems and possible solutions. The World Bank Research Observer 16(2):125-147.

Deaton, Angus. 2010. Price Indexes, Inequality, and the Measurement of World Poverty. The American Economic Review 100(1):5-34.

Dollar, David, and Kraay, Aart. 2004. TRADE, GROWTH, AND POVERTY. The Economic Journal 114(493):F22-F49.

Dreher, Axel. 2006. Does Globalization Affect Growth? Empirical Evidence from a new Index. Applied Economics 38(10):1091-1110.

Dreher, Axel. 2006. The Influence of Globalization on Taxes and Social Policy - an Empirical Analysis for OECD Countries. European Journal of Political Economy 22(1):179-201.

Dreher, Axel, and Gaston, Noel. 2008. Has Globalization Increased Inequality? Review of International Economics 16(3):516-536.

Dreher, Axel, Gaston, Noel, and Martens, Pim. 2008. Measuring Globalisation: Gauging Its Consequences: Springer.

Duncombe, Richard and Richard Heeks. 1999. Information, ICTs and Small Enterprises: Findings from Botswana. Development Informatics Working Paper Series, Paper No. 7 IDPM (Institute for Development Policy and Management), June.

Elbers, C, and Lanjouw, P. 2001. Intersectoral Transfer, Growth, and Inequality in Rural Ecuador. World Development 29(3):481-496.

Fischer, S., and Modigliani, F. 1978. Towards and understanding of he real effects and costs of inflation. Review of World Economics (Wetwirtschaftliches Archiv) 114(4):810-833.

Forestier, Emmanuel, Grace, Jeremy, and Kenny, Charles. 2002. Can information and communication technologies be pro-poor? Telecommunications Policy 26(11):623-646.

Ganuza, Enrique, Morley, Samuel, Pineiro, Valeria, Robinson, Sherman, and Vos, Rob. 2005. Are Export Promotion and Trade Liberalisation Good for Latin America's Poor? Development Policy Revien 23(3):385-404.

Harrison, Ann, and McMillan, Margaret. 2007. On the links between globalization and poverty. Journal of Economic Inequality 5(1):123-134.

Heckelman, J. C, and Stroup, M. D. 2005. A comparison of aggregation methods for measures of economic freedom. European Journal of Political Economy 21(4):953-966. 
Heshmati, Almas. 2007. Income inequality, Poverty and Globalization. In Nissanke, and Thorbecke (Eds.), The impact of globalization on the world's poor.

Heston, A. 1994. A brief review of some problems in using national accounts data in level of output comparisons and growth studies. Journal of Development Economics 44(1):29-52.

Hirschman, A. 1967. Development projects observed. Washington DC: Brookings Institution.

ITU, (International Telecommunications Union). 1998. Rural Telecommunications in Colombia - Lessons Learned. . World Telecommunication Development Conference (WTDC-98), Valletta, Malta, 23 March - 1 April. .

Kalwij, Adriaan, and Verschoor, Arjan. 2007. Not by growth alone: The role of the distribution of income in regional diversity in poverty reduction. European Economic Review 51(4):805-805.

Katircioglu, Salih. 2009. Tourism, trade and growth: the case of Cyprus. Applied Economics 41(21):27412741.

Kawachi, I, and Wamala, S 2007. Globalization and Health. Oxford: Oxford University Press.

Kondoh, Kenji. 1999. Permanent migrants and cross-border workers: The effects on the host country. Journal of Regional Science 39(3):467-478.

Leon, David A. 2008. Cities, urbanization and health. International Journal of Epidemiology 37(1):4-8.

Lindbeck, Assar. 1975. Business Cycles, Politics, and International Economic Dependence. Skandinaviska Enskilden Bank Quarterly Review 2:53-68.

Lundberg, Mattias, and Lyn, Squire. 2003. The Simultaneous Evolution of Growth and Inequality. Economic Journal 113(487):326-344.

Marshall, M G., and Jaggers, K. 2009. Polity IV project. dataset User's Manual.

Medez, A, and Popkin, B.M 2004. Globalization, Urbanization and Nutritional change in the Developing World. Journal of Agricultural and Development Economics 1(2):220-241.

Milanovic, B., and Squire, L. 2006. Does tariff liberalization increase inequality? Some empirical evidence. In A.e. Harrison (Ed.), Globalization and Poverty.: University of Chicago Press NBER (2006).

Mosley, Paul, and Suleiman, Abrar. 2007. Aid, Agriculture and Poverty in Developing Countries. 11:139139.

Pralahad, C. K., and Hammond, Allen. 2002. Serving the World's poor, profitably. Harvard Business Review(September).

Rajan, Raghuram G., and Subramanian, Arvind. 2008. Aid and growth: What does the cross-country evidence really show? The Review of Economics and Statistics 90(4):643-643.

Ravallion, Martin. 2006. Looking Beyond Averages in the Trade and Poverty Debate. World Development 34(8):1374-1374.

Ravallion, Martin. 2010. A Reply to Reddy and Pogge. In S. Anand, P. Segal, and J. Stiglitz (Eds.), Debates in the Measurement of Global Poverty: Oxford University Press.

Ritzer, George. 1996. The McDonaldization Thesis: Is expansion inveitable? International sociology 11(3):291309.

Rodriguez, F, and Rodrik, Dani. 2000. Trade policy and economic growth: a skeptic's guide to the crossnational evidence. NBER Macroeconomics Annual:261-325.

Rodrik, Dani. 1998. Why do more open economies have bigger governments? The Journal of Political Economy 106(5):997-1032.

Sachs, Jeffrey D., and Warner, Andrew. 1995. Economic reform and the process of global integration. Brookings Papers on Economic Activity(1):1-119.

Sindzingre, Alice. 2005. Explaining Threshold Effects of Globalization on Poverty: An Institutional Perspective. World Institute for Development Economic Research (UNU-WIDER), Working Paper RP2005:53.

Sinn, Hans Werner. 1997. The Selection Principle and Market Failure in Systems Competition. Journal of Public Economics 66:247-274.

Snow, John. 1855. On The Mode Of Communication Of Cholera. London: Churchill.

Stark, Oded. 2004. Rethinking the Brain Drain. World Development 32(1):15-22.

Wacziarg, Romain, and Welch, Karen Horn. 2008. Trade Liberalization and Growth: New Evidence. The World Bank Economic Review 22(2):187-231.

Verme, Paolo. 2010. A structural analysis of growth and poverty in the short-term. The Journal of Developing Areas 43(2):19-39.

Whiting, David, and Unwin, Nigel. 2009. Cities, urbanization and health. International journal of epidemiology : official journal of the International epidemiological association 38(6):1737-1738. 
World Bank. 2010. World Development Indicators: World Bank.

Worldbank. 2009. World development report 2009: shaping economic geography. Washington, DC: Världsbanken. Yach, D, Wipfli, H, Hammond, R, and Glantz, S. 2007. Globalization and Tobacco. In I. Kawachi, and S. Wamala (Eds.), Globalization and Health. Oxford: Oxford University Press. 